\title{
Turmoil over the crisis: innovation capabilities and firm exit
}

\author{
Marco Grazzi · Chiara Piccardo • Cecilia Vergari
}

Accepted: 19 March 2021 / Published online: 22 May 2021

(C) The Author(s) 2021

\begin{abstract}
This work investigates the relationship between the characteristics and survival probabilities of firms, distinguishing between "involuntary" firm exit and exit by merger and acquisition (M\&A). More in detail, we study how, and to what extent, innovation capabilities, as proxied by patents and trademarks, are able to shape, together with standard performance variables, the observed dynamics at the firm level. By using comprehensive data on Italian firms from business registers, we separate the administrative procedures leading to "involuntary" exit from those ending up with an event of M\&A. We find that while higher productivity is associated with a lower probability of "involuntary" exit, productivity increases the chances of being the target for M\&A. As far as intellectual property instruments are concerned, they tend to reduce the probability of both "involuntary" exit
\end{abstract}

\author{
M. Grazzi ( $\triangle)$ \\ Department of Economic Policy, Università Cattolica del \\ Sacro Cuore, Milan, Italy \\ e-mail: marco.grazzi@unicatt.it \\ C. Piccardo \\ Department of Economics, University of Verona, 37129 \\ Verona VR, Italy \\ e-mail: chiara.piccardo@univr.it \\ C. Vergari \\ Department of Economics and Management, University of \\ Pisa, 56126 Pisa PI, Italy \\ e-mail: cecilia.vergari@unipi.it
}

and M\&A. However, the relative importance of the two instruments differs according to the exit route: patents are more relevant than trademarks in preventing "involuntary" exit, while the opposite is true for M\&A.

Plain English Summary We investigate firm's exit after a crisis. Overall innovation plays a positive role, but the relative importance of IP depends on the exit route: patents are more relevant than trademarks against "involuntary" exit, while the opposite is true for M\&A. We resort to the virtual universe of Italian limited liability firms from manufacturing, trade, and service to investigate the determinants of firm survival over the period 2010-2014. We scrutinize detailed administrative data on significant events occurring to firms to distinguish between events leading to involuntary exit and to M\&A. In addition to the evidence on innovation, our results show that higher productivity decreases the probability of "involuntary" exit, yet productivity increases the chances of being the target for M\&A. Taken together, these findings warn against a simplistic perspective on exit: the role of innovation and firm characteristics heavily depends on the exit route.

Keywords Firm survival - Firm exit · Mode of exit · Innovation · Patents · Trademarks

JEL Classifications C14 · C20 · D22 · O34 


\section{Introduction}

The economic and financial crisis in the European Union reached its peak in terms of industrial output in 2009 , when the production level fell on average by $14 \%$. After 2 years of recovery with positive growth rates, in 2012, the European Union once again showed negative industrial prospects. In 2014, the EU returned to a positive growth, which continued in 2015 and 2016. ${ }^{1}$

Periods of crisis are expected to have an impact on firms and industrial dynamics. For instance, credit constraints become more stringent and might slow down the process of growth of some firms, while others might be even more severely affected and forced out of business. As a result, periods of crisis might also have an effect, at the more aggregate industry level, on the reallocation of market shares within the industry (see among the others, Foster et al. 2016). As far as we know, only a few studies have analyzed firms' dynamics in the post-crisis period, most of which focus on the short-run impact of the global financial crisis (e.g., Godart et al. 2012; Foster et al. 2016).

In this work, we focus on the post-crisis period (2010-2014) for Italian firms and investigate the relationship between companies' characteristics and their survival probabilities. Our contribution tackles three relevant issues that either tended to be overlooked in the existing literature, or could not be easily addressed simultaneously due to data limitations. First, we distinguish between events leading to "involuntary" firm exit and a rather different mode of exit, by merger and acquisition (M\&A). Second, the analysis of the impact associated with innovation activities on the probability of exit accounts for the distinct role of two Intellectual Property (IP) instruments. In this respect, we focus on granted patents and registered trademarks as a proxy of innovation. Finally, thanks to a dataset covering the complete span of economic activities, we are able to investigate the effects associated with firms' characteristics and with different innovation outputs (patents and trademarks) on the probability of survival (and M\&A) in three broad sectors, respectively, manufacturing, trade, and service.

\footnotetext{
${ }^{1}$ This is documented in the industrial production (volume) index provided by Eurostat: Eurostat Figures.
}

There is a large body of empirical literature focusing on firms' survival. Due to the usual lack of a distinction among the various causes of firms' exit, most of the existing works consider both "voluntary" and "involuntary" exits as homogeneous events, thus analyzing a spurious group of events including not only business failures but also events that are sometimes even related to previous positive performances, such as mergers and acquisitions (M\&A), or events that have nothing to do with performance at all, such as a change of sector of activity or location, even within the same country.

Our main contribution to this strand of literature is the way in which we delineate the exit of firms from the market by focusing on "involuntary" exit and M\&A. In particular, we build our first definition of firm death on the type of administrative procedure a firm is undergoing and we only consider procedures unambiguously leading to "involuntary" exit as causes of the firm's death. This way, contrary to many existing related studies, we are able to identify business failures as costly events, clearly associated with a lack of success.

As a reference for comparison, we also consider a category of events that is clearly distinct from "involuntary" exit. As Schary (1991) points out, a merger is a form of voluntary exit that, unlike unintended modes of exit, tends to preserve most of the productive capacity of the industry. More recently, Coad (2014) emphasizes that there are many cases of entrepreneurial exit, among which M\&A, that are successes rather than failures, as the business continues its operations. As such, it is necessary to properly classify firm exit events to suitably address empirical questions.

Furthermore, unlike many existing contributions that focus on the manufacturing sector, our analysis includes different types of industries. We can thus detect potential differences in firms' survival across the manufacturing, trade, and service sectors. Lastly, to the best of our knowledge, only a few studies have investigated the effect of patent and trademark activity on firms' survival and have identified a positive correlation between these two measures of intellectual property (IP) rights and the expected life span of firms (e.g., Jensen et al. 2008; Buddelmeyer et al. 2010; Helmers and Rogers 2010; Wagner and Cockburn 2010; Masatoshi et al. 2019). As Block 
et al. (2015, p. 1918) point out "patents serve as an indicator of innovation performance because obtaining a patent requires substantial investments of money, time, and labor before an application can be filed and a patent can be granted." As for trademarks, although they do not require comparable ex-ante investments and are less complex, they can also play an important role in firm performance, especially for small- and medium-sized enterprises (SMEs), as SMEs might not, in general, be able to afford other protection mechanisms. According to Flikkema et al. (2014), trademarks are better than existing indicators at capturing "softer" types of (non-technological) innovation, such as service, marketing, and organizational innovation, as well as innovation activities close to the market introduction stage. Moreover, while patents have a finite duration, trademarks do not expire as long as all post-registration maintenance documents are duly filed.

Theoretically speaking, we expect the competitive advantage provided by innovation activities, in our case patents and trademarks, to contribute to improving firm's performance, thus reducing the risk of business failure. In line with the predictions of the selection models of active learning (Ericson and Pakes 1995), successful innovations may thus increase firms' survival chances. Innovation activities, however, are also often associated with uncertainty, so substantial investments may also lead to a higher risk of failure (e.g., Buddelmeyer et al. 2010). On the other hand, innovative firms may become acquisition targets for potential rivals either for efficiency gains (e.g., Perry and Porter 1985) or to increase their market power, or even to preempt mergers by rival companies (e.g., Brito 2003). We can thus conclude that the relationship between innovation and survival is not clear a priori and it might change across the types of exit.

To anticipate the main findings, the empirical evidence suggests that IP instruments are relevant in increasing the survival probabilities of firms, but the relative importance of patents and trademarks depends on the mode of exit under analysis. If, overall, patents appear more important against "involuntary" exit, the opposite is true for M\&A, where trademarks are the IP instrument with the largest effect. Also, more standard performance variables confirm that the two modes of exit display different characteristics: higher produc- tivity decreases the probability of "involuntary" exit, while it increases the probability of exit by M\&A.

The paper is organized as follows. We start by reviewing the strands of literature to which we contribute the most (Section 2). We then describe the data and illustrate the variables of interest (Section 3). Next, we present some preliminary non-parametric evidence based on the Fligner-Policello test of stochastic equality and on the Kaplan-Meier estimator for survival functions (Section 4). Section 5 illustrates our empirical strategy and discusses the empirical results. We provide some concluding comments in Section 6.

\section{Related literature}

Due to the lack of appropriate data, most of the existing studies analyze firms' exits without the possibility of focusing on the specific reasons driving firms to leave the market. As a result of data limitations, "voluntary" and "involuntary" exits are generally pooled together and treated as homogeneous events (see, among others, Jensen et al. 2008; Carreira and Teixeira 2016).

Nevertheless, several attempts have been made to address the issue of firm death more in detail. With this aim, some studies analyze firms' demographic dynamics excluding mergers, acquisitions, and the change of legal form from the causes of exit (e.g., Pérez et al. 2004; Esteve-Pérez and Mañez-Castillejo 2008; Helmers and Rogers 2010; Tsoukas 2011; Delmar et al. 2013; Fackler et al. 2013; Colantone et al. 2015). Others analyze determinants of firms' survival, focusing only on certain modes of exit. For example, Giovannetti et al. (2011) evaluate the impact of size, innovation, and internationalization on Italian firms' survival, considering winding-up, failure, or end of activity as causes of the firms' exit; Godart et al. (2012), using Irish firm-level data, study the effect of the global financial crisis on multinational and domestic firms and define as exiting firms the companies that are in liquidation, dissolved, or in receivership. Similarly, Helmers and Rogers (2010), when investigating the relationship between UK firms' innovative activity and their demographic dynamics, identify as inactive firms the companies 
dissolved, liquidated, in receivership, or declared nontrading. Amendola et al. (2012) and Ferragina et al. (2012) analyze the relationship between Italian firms' involvement in international activities and their survival, by using information from the AIDA Bureau van Dijik (BVD) dataset. These authors called firms' death due to both bankruptcy and liquidation "true exits"; in particular, they do not include among exiting firms the companies that changed their legal form, ownership, sector, or province. Although these works are based on a less spurious definition of firms' death, compared with those used in the studies mentioned above, they still pool together "voluntary" and "involuntary" exits and treat them as homogeneous events.

Within the same stream of literature, some papers examine the effect of firms' characteristics on their probability of leaving the market, distinguishing between different types of exit. For instance, Cefis and Marsili (2012) examine the impact of Dutch manufacturing firms' innovative activity on their probability of exiting the market as a consequence of, in turn, failure, radical restructuring, and M\&A; Wagner and Cockburn (2010), considering a sample of Internetrelated firms that became listed on NASDAQ in the late 1990s, analyze the effect of innovation on the probability of delisting from the NASDAQ due to, in turn, bankruptcy and M\&A. Similarly, Esteve-Pérez et al. (2010) focus on the impact of firm and industry characteristics on firm survival in a sample of Spanish firms, distinguishing between firms' death due to liquidation and bankruptcy and firms' exit due to M\&A. More recently, Balcaen et al. (2012), using data on Belgian firms, identify firm-level characteristics that impact firms' probability both of bankruptcy and of voluntary exit (i.e., exit which occurs through voluntary liquidation or M\&A). Masatoshi et al. (2019) also distinguish between bankruptcy, voluntary liquidation, and merger to investigate the survival of new firms in the Japanese manufacturing and information services sectors. Headd (2003) studies closure rates of new firms, distinguishing between successful and unsuccessful closures as defined by the owners (US survey data). Finally, Elfenbein and Knott (2015) consider two forms of exit: failure (a "paid-out" or a "forced merger," according to the Federal Deposit Insurance Corporation), and unforced merger of firms that are acquired or merge voluntarily. These authors review the main theories of firms' exit delays and test the importance of different delay mechanisms by investigating the exit timing of US banks between 1984 and $1997 .^{2}$ All these works found that the determinants of firms' exit vary according to different types of exit considered.

To the best of our knowledge, only a few studies focus on the analysis of "involuntary" exits, and yet they could do this only by focusing on a particular subset of firms and on specific forms of firm exit. Bottazzi et al. (2011) investigate the role of firms' financial and economic performances as determinants of firm exits from the market over a large sample of Italian firms. The authors proxy "involuntary" exit by firms' financial default and recall that "Like firm failures, default events are both a signal of business troubles and a costly condition that should be in principle avoided. Even if default is not directly related with exit, it constitutes the main requisite for initiating the bankruptcy procedures" (Bottazzi et al. 2011, p. 375). More recently, Mueller and Stegmaier (2015) give exclusive attention to "involuntary plant closures" defined as exit from the market due to the conclusion of bankruptcy processes. As stated by the authors, however, the main weakness of their approach is the exclusion from their definition of firms' death of all the "involuntary" closures which are not due to a bankruptcy filing. As we mentioned above, we seek to overcome this weakness in the definition of firms' exit by considering, as causes of firms' closure, only the administrative procedures that unambiguously lead to an "involuntary" exit, or to M\&A. Furthermore, we can also resort to the virtual universe of Italian limited liability firms, independently of their size. The absence of a size threshold is particularly important when investigating firms' demographics, as small firms are the big player when it comes to entry and exit.

\section{Data and variables of interest}

The empirical analysis is based on a firm-level panel dataset for Italian companies built on the merger

\footnotetext{
${ }^{2}$ The delay is defined with respect to the Marshallian exit decision rule with perfect information, and the delay mechanisms are: uncertainty about firms' efficiency or market demand and/or the presence of sunk re-entry costs (rational delay); cognitive bias that induce managers to overestimate future profitability relative to rational benchmark (behavioral delay); and agency problems in case of multiple stakeholders or non-owner manager (organizational delay).
} 
of AIDA (Analisi Informatizzata delle Aziende) and AMADEUS data, respectively Bureau van Dijk (2019a) and Bureau van Dijk (2019b).

The AIDA dataset includes detailed information on Italian limited liability companies operating in both the manufacturing and services sectors, which have to report their balance sheet to the Italian Chambers of Commerce. The data provide financial and economic information for Italian firms, as well as a wide set of relevant indicators, including number of employees, incorporation year, sector of activity, and administrative procedures underwent by the firms.

AIDA, due to its nature, covers virtually ${ }^{3}$ the universe of Italian limited liability firms ${ }^{4}$ independently of their size, thus representing the ideal set of data to study the dynamics of firms and industries. This peculiarity is crucial for the accurate analysis of firms' entry and exit from the market as typically newborn firms are characterized by a smaller size. As a consequence, employing a dataset with a threshold on firm size would misrepresent entry and exit processes. The absence of size threshold is also reflected in the high number of observations per year, around 600 thousands (refer to Table 7).

We integrate AIDA data with information on the stock of granted patents and registered trademarks owned by firms in each relevant year derived from the other BvD sources. As for patents, AMADEUS provides some relevant information, including international patent classification (IPC) codes, the application date, the number of citing documents, and whether a patent has been granted or not; while, for filed trademarks, one can resort to NICE classification code, the filing date and information on their registration.

In the remainder of this section, we provide detailed information on the definition of the variables related to exit and to innovation, as well as descriptive evidence on the dataset. Further information on the construction of the dataset and its representativeness of the Italian economy are included in a self-contained Data Appendix at the end, while the step-by-step procedures that allow the replication of the full dataset are reported in Grazzi et al. (2018).

\footnotetext{
${ }^{3}$ To comply with the law, limited liability firms have to report their financial statement, together with additional information, to the local Chamber of Commerce. Hence, as reported on the homepage of AIDA, at least in principle, the database includes all limited liability firms.

${ }^{4}$ The unit of analysis is the firm, not the plant.
}

\section{1 "Involuntary" exit and M\&A}

Concerning the investigation of firms' death, we start by focusing on "involuntary" exit and we build our definition of firms' exit on the type of administrative procedures underwent by the firm. In particular, we identify the following administrative procedures that unambiguously lead to an "involuntary" exit: bankruptcy, cancellation due to communication of allocation plan, cancellation ex officio from the register of companies, cancellation from the register of companies, composition with creditors, compulsory administrative liquidation, court order of cancellation, failure to meet prerequisites, impossibility of fulfillment of the company object, initial failure to meet the prerequisites for a company, no longer meeting requirements, post-bankruptcy composition with creditors, removal ex officio, supervening failure to meet the prerequisites for a company, and winding up by official order. Accordingly, we label an exit as "involuntary" if caused by one of the administrative procedures listed above. Most importantly, our definition of "involuntary" exit does not include all the events of exits that can be assimilated to "voluntary" exit, or that are merely related to complying with bureaucratic procedures, that is, more in detail: "voluntary" exit (e.g., "approved by all partners" and "voluntary liquidation"), firms' change of sector or province (e.g., "cessation of business within a province" and "transfer to another province"), and merger and acquisition (included "demerger," "duplication," "contribution," "lease of company," and "transfer of firm"). Moreover, we do not account for administrative procedures which do not unequivocally lead to an "involuntary" exit. For example, we do not consider "liquidation" and "closure due to bankruptcy or liquidation" as cause of firms' failure, among others. Note that liquidation can be both voluntary and involuntary; thus, we do not account for "liquidation" and "closure due to bankruptcy or liquidation" because the data do not provide any other specification and do not allow us to make a clear distinction between voluntary and involuntary liquidation. ${ }^{5}$

Note that in Italy, the administrative procedures leading to firm exit are lengthy, they might take several

\footnotetext{
${ }^{5}$ This lack of information implies that we might underestimate the number of "involuntary" exits.
} 
years, ${ }^{6}$ and might be particularly intricate, meaning that our source of information, which ultimately is the business register, might report several administrative procedures initiated by any single firm before the final exit. It is also common that several years elapse between the start of the first procedure and the formal exit from the market. In order to correctly identify the time of "economic" exit, and not of the formal or legal exit, we focus our attention on the first year in which such procedures have been initiated, for those firms that eventually exited the market also formally. Note that by construction, this determines a drop in the number of exits in the last two years of observations, as apparent from Table 1 . In particular, if a firm underwent more than one procedure generating an "involuntary" exit, we impute the firm's exit to the year of the first relevant administrative procedure. Moreover, we anticipate the year of exit to the last year in which the firm reported the balance sheet if it is prior to the year in which the firm underwent one of the relevant administrative procedures. ${ }^{7}$

In Appendix A, Table 8, we report how administrative procedures determine firms' "involuntary" exit in our analysis. The table shows that the administrative procedures that mainly lead to "involuntary" exit are the following: "Cancellation from the register of companies," "Bankruptcy," "Composition with creditors," and "Compulsory administrative liquidation." This evidence is suggesting that, in each year, for most of the firms that had not initiated procedures related to "voluntary" exit, the first procedure that is reported in the business register is cancellation.

Furthermore, for the sake of comparison, we identify a second type of exit, that is, firms' exit through M\&A. We label an exit as M\&A if caused by the administrative procedure "merger by incorporation into another company." Note that while there of course exist other routes to firm exit, the two modes that we identify, "involuntary" and M\&A, are mutually exclusive, hence for instance, a firm that reported "merger

\footnotetext{
${ }^{6}$ This is especially the case for firms which are employers, as those we are considering in the empirical analysis.

${ }^{7}$ It is worth noting that AIDA removes from the dataset companies not reporting the balance sheet in the previous 5 years. Thus, we do not consider firms which do not report any relevant administrative procedures but that exit from the dataset at some point during the period of analysis.
}

by incorporation into another company" did not initiated any of the administrative procedures associated to "involuntary exit."

This distinction across exit modes allows us to verify whether firms' characteristics differently affect firms' probability of exit due to business failure ("involuntary" exit) and firms' successful exit (M\&A).

In this work, we can resort to balance sheet data information from 2005 to 2014 that we employ to study firms' exit in the post-crisis period, from 2010 to $2014 .{ }^{8}$ To provide a comparison with other sources, consider that figures for "gross" exit rates (thus not restricted to "involuntary") are much in line with the official statistics reported by Infocamere, which gathers data from all Italian Chambers of Commerce. In $2013,5.161 \%$ of firms exited according to data from $\mathrm{BvD}$ and $5.410 \%$ according to Infocamere, see also Table 7 in the Appendix.

Table 1 resumes entry and exit dynamics for the period 2010-2014 based on our definition of entry, "involuntary" exit and exit by M\&A. We show statistics distinguishing between firms operating in the manufacturing, trade, and service sectors. ${ }^{9}$

Data show that, irrespective of the sector considered, during the period of interest, the rate of firms' entry, defined as the ratio of entrants on active firms, is higher than the rate of "involuntary" exit, defined as the ratio of exiting firms on active firms. Moreover, as expected, data suggest that the rate of exit through M\&A, defined as the ratio of firms involved in M\&A on active firms, is much lower than the share of "involuntary" exit. The share of "involuntary" exiting firms is about $2.4 \%$ for all sectors, while entry rates differ across sectors: they are higher for trade and services (on average, around $7.8 \%$ and $8.4 \%$, respectively) than

\footnotetext{
${ }^{8}$ We use two AIDA DVDs available in December 2015 and December 2016, respectively. The resulting dataset covers the period between 2005 and 2014; however, valuable information on firms exit are only available for the years 2010-2014. Indeed, as suggested by the $\mathrm{BvD}$, the data section about administrative procedures has been added in AIDA only in December 2010. Moreover, preliminary exploratory analysis reveals that in most cases there is a reporting lag of about 2 years; hence, in the AIDA dataset the last available year for firms' exiting information is 2014 .

${ }^{9}$ In the manufacturing sector, we do not account for firms operating in the 2 digit sectors 12 and 33 of Nace Rev. 2. In the trade sector, we only include firms in Section G. We do not include in the service sector firms operating in the following Nace Rev. 2 Sections: D, E, F, I, K, L, O, T, and U. See Appendix A, Table 6, for more details.
} 
Table 1 Entry and exit according to our definition of "involuntary" exit and exit by M\&A

\begin{tabular}{|c|c|c|c|c|c|c|c|}
\hline Year & Entries & Invol. Exits & $\mathrm{M} \& \mathrm{~A}$ & Active & $\%$ Entries & $\%$ Invol. Exits & $\% \mathrm{M} \& \mathrm{~A}$ \\
\hline \multicolumn{8}{|c|}{ BOX A: Manufacturing sector } \\
\hline 2010 & 4762 & 3287 & 594 & 106,326 & 4.479 & 3.091 & 0.559 \\
\hline 2011 & 4517 & 3137 & 577 & 107,129 & 4.216 & 2.928 & 0.539 \\
\hline 2012 & 4689 & 2890 & 553 & 108,375 & 4.327 & 2.667 & 0.510 \\
\hline 2013 & 5698 & 1639 & 372 & 112,062 & 5.085 & 1.463 & 0.332 \\
\hline 2014 & 6200 & 1284 & 412 & 116,566 & 5.319 & 1.102 & 0.353 \\
\hline \multicolumn{8}{|c|}{ BOX B: Trade sector } \\
\hline 2010 & 9294 & 4,85 & 540 & 127,658 & 7.280 & 3.592 & 0.423 \\
\hline 2011 & 9427 & 4233 & 579 & 132,273 & 7.127 & 3.200 & 0.438 \\
\hline 2012 & 10,065 & 4108 & 514 & 137,716 & 7.309 & 2.983 & 0.373 \\
\hline 2013 & 12,393 & 2077 & 394 & 147,638 & 8.394 & 1.407 & 0.267 \\
\hline 2014 & 14,453 & 1817 & 426 & 159,848 & 9.042 & 1.137 & 0.267 \\
\hline \multicolumn{8}{|c|}{ BOX C: Service sector } \\
\hline 2010 & 14,246 & 5914 & 859 & 168,751 & 8.442 & 3.505 & 0.509 \\
\hline 2011 & 13,880 & 5770 & 1034 & 175,827 & 7.894 & 3.282 & 0.588 \\
\hline 2012 & 14,462 & 5531 & 938 & 183,820 & 7.867 & 3.009 & 0.510 \\
\hline 2013 & 16,808 & 2549 & 622 & 197,457 & 8.512 & 1.291 & 0.315 \\
\hline 2014 & 20,307 & 2475 & 739 & 214,550 & 9.465 & 1.154 & 0.344 \\
\hline
\end{tabular}

Note: We only consider firms operating in manufacturing or service sectors with information on both their entry and exit ("involuntary" or M\&A)/survival (we exclude firms operating in the 2 digit Nace Rev.2 codes 12 and 33 and in the following Sections Nace Rev.2: D, E, F, I, K, L, O, T, U)

for manufacturing firms (around 4.7\%). Conversely, the rate of firms exiting by M\&A does not significantly differ across sectors and it is on average around $0.4 \%$.

\subsection{Innovative activities}

The analysis of the effects of innovation activities on firms' performance has a long tradition in the literature, with most contributions focusing on the role of R\&D and patents, especially among large and medium firms. Starting with Griliches (1981), many authors investigated the relationship between firm's market value and its $R \& D$ expenditures and number of patents, often focusing on large quoted companies (see, e.g., Toivanen et al. 2002; Hall 2000). More recently, scholars also started to investigate the role of other IP instruments, with a particular focus on trademarks, see for instance (Mendonça et al. 2004). Trademarks, beside patents, provide a useful proxy for firms' innovation activity. This is even more true for SMEs and for "softer" types of (non-patentable, non-technological) innovation like service, marketing, and organizational innovations as well as innovation activities closer to the market introduction stage (see, e.g., Flikkema et al. 2014, 2019; Helmers and Rogers 2010).

Moreover, scholars started to analyse not only how innovation activities might improve firm performance but also their impact on firm survival, on the one side, and on the mode of exit, on the other (see Fontana and Nesta 2009; Cefis and Marsili 2012; Børing 2015; Landini et al. 2020, among the others).

In contributing to the two strands of literature recalled above, we focus on the role of innovation output as proxied by patents and trademarks in shaping the survival probabilities of firms. ${ }^{10}$ In this respect, we focus on granted patents that have been applied at the United States Patent and Trademark Office (USPTO) or at the European Patent Office (EPO) and

\footnotetext{
${ }^{10}$ Note that in order to exploit the universe of firms, we would rather not resort to innovation surveys or other proxies of innovation efforts, such as R\&D expenditures whose coverage in terms of available data is limited.
} 
on registered trademarks that have been filed at the United States Patent and Trademark Office (USPTO) or at the European Union Intellectual Property Office (EUIPO), formerly known as Office for Harmonization in the Internal Market (OHIM). Moreover, given the low propensity of Italian firms to apply for patents on international markets, we even consider granted patents that have been applied only at the Italian Patent and Trademark Office (IPTO). In order to define the stock of granted patents for each firm, in each relevant year, we consider only patents applied before or in the year of interest; also, as the dataset does not provide information about the patent expiration date, we consider a 20-year maximal time span of validity, that is, the stock of patents for each firm, in each year, does not include patents applied more than 20 years before the year of interest (i.e., if a patent has been applied in the 1991 by a firm, we include it in the count up to 2010). ${ }^{11}$ The 20 -year time span for patents seems reasonable in order not to account for patents which are too "old" as a proxy of firms' technological capabilities. Furthermore, 20 years also corresponds to the time span of the legal protection granted by law. We are aware of the depreciation of patents over time (de Rassenfosse and Jaffe 2018, see among the others); however, given the very small number of Italian firms holding patents, we opt for not discounting patents, in order to not further restrict the sample.

In addition to patents, we identify the stock of registered trademarks for each firm, in each relevant year, by only considering trademarks applied before or in the year of interest that expire after the year of interest. Based on the yearly number of granted patents and registered trademarks, we build two dummy variables which indicate if a firm, in each year, is holding granted patents or registered trademarks, respectively. ${ }^{12}$

\subsection{Other variables and descriptive statistics}

In this section, we provide a brief illustration of the other variables employed in the empirical analysis, together with descriptive evidence to appreciate trend over time and differences across sectors.

Table 2 shows some descriptive statistics in each year of the analysis (2010-2014), and for each sector. Manufacturing firms are, on average, almost twice as big as service firms, while firms in trade sector are the smallest. Size is here proxied by the number of employees (Empl). As expected, firms' size distribution is much asymmetric irrespective of the sector in which firms operate (plots are not reported).

The average value added (Value Added) is slightly decreasing over time in all sectors. As expected, value added is higher in manufacturing than in trade or service sectors. ${ }^{13}$ There is no noteworthy trend over time in terms of return on sales in each sector $(R O S)$, as measured by operative profits over sales (in percentage points). On average, firms' profitability is 3\% in the manufacturing and service sectors and $2 \%$ in the trade sector. Firms' financial stability is measured by the solvency ratio (SolvRatio), which is calculated by dividing total equity by total assets (in percentage points). The solvency ratio is stable over time: on average, the share of assets that are internally financed is around $28 \%, 26 \%$, and $31 \%$ in the manufacturing, trade and service sectors, respectively. ${ }^{14}$ We use firms' age (Age), defined as the difference between the year of interest and incorporation year plus 1 (Age is equal to one in the incorporation year), as proxy for firms' experience.

Firms' innovative capacity is measured by two dummy variables taking value one if firms own granted patents (val_pat_d) and registered trademarks (val_trade_d), respectively, and zero otherwise. Data show a low propensity of Italian firms to file for patents or trademarks. Indeed, only a small fraction of firms can be defined as innovators, according to such definition, over the period considered.

\footnotetext{
${ }^{13}$ In the following analysis, we will employ labor productivity $(L P)$ as measured by the ratio between value added and number of employees.

${ }^{14}$ AIDA data only provide firms' solvency ratio ranging between -50 and 100 .
}

\footnotetext{
${ }^{11}$ Note that this time span is not binding for firms younger than 20 years, so that this choice does not reduce the sample. The 20 year time span is also in accordance to international standard see among the others Gallini 2002; Ginarte and Park 1997).

${ }^{12}$ As we employ the counts of patents only to define dummies, we are confident that applying a depreciation rate does not significantly affect results.
} 
Table 2 Descriptive statistics by sector of activity

\begin{tabular}{|c|c|c|c|c|c|}
\hline & 2010 & 2011 & 2012 & 2013 & 2014 \\
\hline \multicolumn{6}{|c|}{ Box A - manufacturing } \\
\hline Empl & $\begin{array}{l}22.960 \\
(157.110)\end{array}$ & $\begin{array}{l}24.882 \\
(158.173)\end{array}$ & $\begin{array}{l}23.855 \\
(138.419)\end{array}$ & $\begin{array}{l}23.170 \\
(154.939)\end{array}$ & $\begin{array}{l}22.156 \\
(159.402)\end{array}$ \\
\hline Value Added & $\begin{array}{l}1439.384 \\
(10918.86)\end{array}$ & $\begin{array}{l}1408.727 \\
(10615.28)\end{array}$ & $\begin{array}{l}1318.095 \\
(9851.12)\end{array}$ & $\begin{array}{l}1322.652 \\
(10063.48)\end{array}$ & $\begin{array}{l}1317.429 \\
(10439.96)\end{array}$ \\
\hline $\operatorname{ROS}(\%)$ & $\begin{array}{l}3.098 \\
(9.520)\end{array}$ & $\begin{array}{l}3.365 \\
(9.475)\end{array}$ & $\begin{array}{l}2.719 \\
(9.877)\end{array}$ & $\begin{array}{l}3.091 \\
(9.816)\end{array}$ & $\begin{array}{l}3.412 \\
(9.951)\end{array}$ \\
\hline SolvRatio & $\begin{array}{l}28.047 \\
(25.203)\end{array}$ & $\begin{array}{l}27.960 \\
(25.232)\end{array}$ & $\begin{array}{l}28.657 \\
(25.724)\end{array}$ & $\begin{array}{l}28.672 \\
(25.895)\end{array}$ & $\begin{array}{l}28.605 \\
(26.230)\end{array}$ \\
\hline Age & $\begin{array}{l}18.079 \\
(14.916)\end{array}$ & $\begin{array}{l}18.424 \\
(15.093)\end{array}$ & $\begin{array}{l}18.702 \\
(15.264)\end{array}$ & $\begin{array}{l}18.725 \\
(15.413)\end{array}$ & $\begin{array}{l}18.735 \\
(15.577)\end{array}$ \\
\hline Val_trade_d & $\begin{array}{l}0.065 \\
(0.246)\end{array}$ & $\begin{array}{l}0.069 \\
(0.254)\end{array}$ & $\begin{array}{l}0.074 \\
(0.261)\end{array}$ & $\begin{array}{l}0.075 \\
(0.264)\end{array}$ & $\begin{array}{l}0.071 \\
(0.258)\end{array}$ \\
\hline Val_pat_d & $\begin{array}{l}0.060 \\
(0.238)\end{array}$ & $\begin{array}{l}0.059 \\
(0.236)\end{array}$ & $\begin{array}{l}0.057 \\
(0.231)\end{array}$ & $\begin{array}{l}0.052 \\
(0.222)\end{array}$ & $\begin{array}{l}0.047 \\
(0.213)\end{array}$ \\
\hline \multicolumn{6}{|c|}{ Box B - trade sector } \\
\hline Empl & $\begin{array}{l}8.872 \\
(121.198)\end{array}$ & $\begin{array}{l}10.493 \\
(141.972)\end{array}$ & $\begin{array}{l}9.648 \\
(110.644)\end{array}$ & $\begin{array}{l}9.338 \\
(122.248)\end{array}$ & $\begin{array}{l}8.499 \\
(106.245)\end{array}$ \\
\hline Value Added & $\begin{array}{l}510.38 \\
(6456.577)\end{array}$ & $\begin{array}{l}490.511 \\
(6264.428)\end{array}$ & $\begin{array}{l}434.433 \\
(5900.42)\end{array}$ & $\begin{array}{l}412.611 \\
(5975.445)\end{array}$ & $\begin{array}{l}386.512 \\
(5944.292)\end{array}$ \\
\hline $\operatorname{ROS}(\%)$ & $\begin{array}{l}2.472 \\
(9.250)\end{array}$ & $\begin{array}{l}2.481 \\
(9.351)\end{array}$ & $\begin{array}{l}1.839 \\
(9.768)\end{array}$ & $\begin{array}{l}1.869 \\
(9.944)\end{array}$ & $\begin{array}{l}2.010 \\
(10.161)\end{array}$ \\
\hline SolvRatio & $\begin{array}{l}26.439 \\
(25.811)\end{array}$ & $\begin{array}{l}26.384 \\
(25.966)\end{array}$ & $\begin{array}{l}27.030 \\
(26.461)\end{array}$ & $\begin{array}{l}27.024 \\
(26.786)\end{array}$ & $\begin{array}{l}26.988 \\
(27.261)\end{array}$ \\
\hline Age & $\begin{array}{l}13.966 \\
(13.086)\end{array}$ & $\begin{array}{l}14.064 \\
(13.176)\end{array}$ & $\begin{array}{l}14.106 \\
(13.258)\end{array}$ & $\begin{array}{l}13.927 \\
(13.286)\end{array}$ & $\begin{array}{l}13.670 \\
(13.295)\end{array}$ \\
\hline Val_trade_d & $\begin{array}{l}0.017 \\
(0.129)\end{array}$ & $\begin{array}{l}0.019 \\
(0.136)\end{array}$ & $\begin{array}{l}0.020 \\
(0.141)\end{array}$ & $\begin{array}{l}0.021 \\
(0.143)\end{array}$ & $\begin{array}{l}0.019 \\
(0.138)\end{array}$ \\
\hline Val_pat_d & $\begin{array}{l}0.009 \\
(0.096)\end{array}$ & $\begin{array}{l}0.009 \\
(0.093)\end{array}$ & $\begin{array}{l}0.008 \\
(0.090)\end{array}$ & $\begin{array}{l}0.007 \\
(0.085)\end{array}$ & $\begin{array}{l}0.006 \\
(0.079)\end{array}$ \\
\hline \multicolumn{6}{|c|}{ Box C - service sector } \\
\hline Empl & $\begin{array}{l}12.607 \\
(467.411)\end{array}$ & $\begin{array}{l}15.137 \\
(415.032)\end{array}$ & $\begin{array}{l}14.572 \\
(394.135)\end{array}$ & $\begin{array}{l}14.127 \\
(377.871)\end{array}$ & $\begin{array}{l}13.096 \\
(350.906)\end{array}$ \\
\hline Value Added & $\begin{array}{l}798.699 \\
(36552.44)\end{array}$ & $\begin{array}{l}757.204 \\
(33729.72)\end{array}$ & $\begin{array}{l}690.577 \\
(30328.66)\end{array}$ & $\begin{array}{l}643.385 \\
(26785.14)\end{array}$ & $\begin{array}{l}602.015 \\
(23946.08)\end{array}$ \\
\hline $\operatorname{ROS}(\%)$ & $\begin{array}{l}3.428 \\
(11.667)\end{array}$ & $\begin{array}{l}3.566 \\
(11.619)\end{array}$ & $\begin{array}{l}2.922 \\
(11.944)\end{array}$ & $\begin{array}{l}2.820 \\
(11.931)\end{array}$ & $\begin{array}{l}3.035 \\
(12.089)\end{array}$ \\
\hline SolvRatio & $\begin{array}{l}31.6967 \\
(29.432)\end{array}$ & $\begin{array}{l}31.700 \\
(29.478)\end{array}$ & $\begin{array}{l}32.063 \\
(29.645)\end{array}$ & $\begin{array}{l}31.996 \\
(29.967)\end{array}$ & $\begin{array}{l}32.034 \\
(30.329)\end{array}$ \\
\hline Age & $\begin{array}{l}11.686 \\
(10.978)\end{array}$ & $\begin{array}{l}11.854 \\
(11.070)\end{array}$ & $\begin{array}{l}11.998 \\
(11.152)\end{array}$ & $\begin{array}{l}11.993 \\
(11.189)\end{array}$ & $\begin{array}{l}11.872 \\
(11.221)\end{array}$ \\
\hline Val_trade_d & $\begin{array}{l}0.012 \\
(0.109)\end{array}$ & $\begin{array}{l}0.014 \\
(0.116)\end{array}$ & $\begin{array}{l}0.015 \\
(0.122)\end{array}$ & $\begin{array}{l}0.016 \\
(0.125)\end{array}$ & $\begin{array}{l}0.014 \\
(0.119)\end{array}$ \\
\hline val_pat_d & $\begin{array}{l}0.006 \\
(0.079)\end{array}$ & $\begin{array}{l}0.006 \\
(0.077)\end{array}$ & $\begin{array}{l}0.006 \\
(0.075)\end{array}$ & $\begin{array}{l}0.005 \\
(0.071)\end{array}$ & $\begin{array}{l}0.004 \\
(0.066)\end{array}$ \\
\hline
\end{tabular}

Note: We exclude firms operating in 2 digit Nace Rev. 2 codes 12 and 33 and in the following macro-section Nace Rev.2: D, E, F, I, K, L, O, T, U. Empl is the number of employees in units, Value Added is in thousands of Euros, ROS and SolvRatio are percentages, Age is the number of years, Val_trade_d and val_pat_d are dummy variables for patents and trademarks. The table displays means and standard deviations (in brackets) 
Firms in the manufacturing sector are more incline to apply for IP than firms operating in the trade or service sectors. Indeed, on average, $7 \%$ of firms in the manufacturing sector owned at least one registered trademark, and around 5\% has at least one granted patent; while in the trade and service sectors, the share of firms with at least one patent (on average $0.78 \%$ and $0.54 \%$, respectively) or one trademark $(1.92 \%$ and $1.41 \%)$ decreases. For a detailed analysis of the complementarity existing between patents and trademarks over the same period, refer to Grazzi et al. (2020).

Geographical dummies, accounting for North, Center, or South macro-regions, show that most firms (around 52\%) are located in the North of Italy and slightly more than $20 \%$ are located in the Center and South of Italy, respectively. ${ }^{15}$

\section{Non-parametric evidence}

Before proceeding with more standard econometric analysis, we introduce some preliminary nonparametric evidence derived from the Fligner and Policello (1981) test of stochastic equality, FP henceforth, and from the Kaplan-Meier estimator. The former allows us to compare "continuing" and exiting firms (by "involuntary" exit and by M\&A); the latter estimator allows us to compare survival between innovative and non-innovative firms.

\subsection{Comparing "continuing" and exiting firms}

We start our non-parametric analysis by comparing "continuing" firms with those exiting in each year of interest (2010-2014) looking at their performance in earlier years (from 2005). To compare groups of firms, we distinguish between "involuntary" exiting firms and exiting firms by M\&A. In particular, we focus on firms' size, productivity, profitability,

\footnotetext{
${ }^{15}$ Table 2 does not report statistics for geographical area dummy variables because evidence are strongly stable over the period considered. They are available upon request.
}

solvency ratio, and age. We employ the FP test as it is suited to perform comparison of uneven samples, ${ }^{16}$ indeed as shown in Section 3, exiting firms (both through "involuntary" exit and M\&A) represent only a small fraction of the reference population. Moreover, within the class of non-parametric tests for comparison of uneven samples, the FP test is appropriate to deal with known non-normalities, unequal variance, asymmetry, and unequal shapes.

More in detail, let $F_{A}$ and $F_{E}$ be the distributions of the relevant variables of "continuing" firms and exiting firms, respectively. Denote with $\mathbf{X}_{A} \sim F_{A}$ and $\mathbf{X}_{E} \sim F_{E}$ the associated random variables, and with $X_{A}$ and $X_{E}$ the two respective realizations. Based on the FP test, the distribution $F_{A}$ is said to stochastically dominate $F_{E}$ if $\operatorname{Prob}\left\{X_{A}>X_{E}\right\}>1 / 2 .{ }^{17}$

For each relevant variable, we compare "continuing" firms with those exiting, in years 2014, 2013, 2012, 2011, and 2010, respectively, looking at their characteristics in earlier years (from 2005). A positive sign of the FP statistic implies that "continuing" firms have a higher likelihood to take on larger values of a given variable (i.e., the distribution of the relevant variable for "continuing" firms stochastically dominates the distribution of the same variable for exiting firms); and the opposite holds if the statistic assumes a negative sign. In the interest of space, Table 3 only reports FP tests comparing "continuing" firms with those exiting in 2012. ${ }^{18}$ Box A is referred to "involuntary" exit and Box B to M\&A. Each column in Table 3 reports the results of the comparison between the two groups of firms, "continuing" and exiting in 2012, from 1 to 7 years before. For each variable and year, we report the FP statistic and significance $(* p<0.10$, $* * p<0.05, * * * p<0.01)$.

\footnotetext{
${ }^{16} \mathrm{We}$ cannot perform the FP test on patents and trademarks dummy variables, because the test only allows to compare distributions of continuous variables between groups. We will resort to the Kaplan-Meier estimator in Section 4.2 to investigate those variables.

${ }^{17}$ The null hypothesis in the FP test implies equality of median among distributions.

${ }^{18}$ FP tests considering other years of exit are similar to Table 3 and are available upon request.
} 
Table 3 Fligner-Policello test: "continuing” firms in 2012 vs exiting firms in 2012

\begin{tabular}{|c|c|c|c|c|c|c|c|c|}
\hline & & 2011 & 2010 & 2009 & 2008 & 2007 & 2006 & 2005 \\
\hline \multicolumn{9}{|c|}{ BOX A: "involuntary" exit } \\
\hline \multirow[t]{5}{*}{ Manuf. } & $\ln (\mathrm{Empl})$ & -0.815 & -0.551 & $-2.899 * * *$ & $-2.268 * *$ & -1.335 & $-1.705^{*}$ & -0.322 \\
\hline & $\ln (\mathrm{LP})$ & $18.151 * * *$ & $9.743 * * *$ & $8.862 * * *$ & $7.769 * * *$ & $7.259 * * *$ & $5.855 * * *$ & $6.344 * * *$ \\
\hline & ROS & $23.596 * * *$ & $15.740 * * *$ & $10.403 * * *$ & $9.661 * * *$ & $9.854 * * *$ & $8.010^{* * *}$ & $7.138 * * *$ \\
\hline & SolvRatio & $40.482 * * *$ & $32.604 * * *$ & $26.780 * * *$ & $22.678 * * *$ & $20.013^{* * *}$ & $20.139 * * *$ & $18.426^{* * *}$ \\
\hline & $\ln ($ Age $)$ & $10.080 * * *$ & $9.911 * * *$ & $9.784 * * *$ & $8.130 * * *$ & $6.600 * * *$ & $5.548 * * *$ & $5.047 * * *$ \\
\hline \multirow[t]{5}{*}{ Trade } & $\ln (\mathrm{Empl})$ & $1.699 * *$ & -0.090 & -0.954 & $-2.296^{* *}$ & -0.203 & -0.405 & -0.595 \\
\hline & $\ln (\mathrm{LP})$ & $14.260 * * *$ & $7.769 * * *$ & $8.007 * * *$ & $8.390 * * *$ & $4.549 * * *$ & $3.937 * * *$ & $2.920 * * *$ \\
\hline & ROS & $16.333 * * *$ & $12.191 * * *$ & $9.335 * * *$ & $8.135 * * *$ & $5.441 * * *$ & $5.423 * * *$ & $5.483 * * *$ \\
\hline & SolvRatio & $26.783 * * *$ & $22.725 * * *$ & $18.951 * * *$ & $15.405^{* * *}$ & $12.204 * * *$ & $12.909 * * *$ & $11.093 * * *$ \\
\hline & $\ln ($ Age $)$ & $11.102 * * *$ & $10.981 * * *$ & $10.283 * * *$ & $9.297 * * *$ & $8.782 * * *$ & $7.749 * * *$ & $6.560 * * *$ \\
\hline \multirow[t]{5}{*}{ Service } & $\ln (\mathrm{Empl})$ & 0.285 & -0.859 & -0.646 & $-1.865^{*}$ & -0.316 & -0.769 & -0.447 \\
\hline & $\ln (\mathrm{LP})$ & $7.555 * * *$ & $6.224 * * *$ & $5.812 * * *$ & $5.178 * * *$ & $3.540 * * *$ & $3.171 * * *$ & $2.940 * * *$ \\
\hline & ROS & $15.237 * * *$ & $10.002 * * *$ & $9.707 * * *$ & $7.331 * * *$ & $8.774 * * *$ & $7.151 * * *$ & $6.100 * * *$ \\
\hline & SolvRatio & $20.048 * * *$ & $15.217 * * *$ & $13.456 * * *$ & $11.150 * * *$ & $8.967 * * *$ & $11.981 * * *$ & $10.392 * * *$ \\
\hline & $\ln ($ Age $)$ & $13.602 * * *$ & $13.172 * * *$ & $10.935^{* * *}$ & $9.660 * * *$ & $8.906 * * *$ & $7.396 * * *$ & $6.083 * * *$ \\
\hline \multicolumn{9}{|c|}{ BOX B: exit by M\&A } \\
\hline \multirow[t]{5}{*}{ Manuf. } & $\ln (\mathrm{Empl})$ & $-3.783 * * *$ & $-4.075 * * *$ & $-4.650 * * *$ & $-4.072 * * *$ & $-3.542 * * *$ & $-3.113 * * *$ & $-2.281 * *$ \\
\hline & $\ln (\mathrm{LP})$ & $-6.083 * * *$ & $-2.705 * * *$ & $-3.203 * * *$ & $-2.253^{* *}$ & $-2.796 * * *$ & $-3.667 * * *$ & -0.691 \\
\hline & ROS & $5.175 * * *$ & $5.423 * * *$ & $3.636 * * *$ & $4.124 * * *$ & $3.570 * * *$ & $1.712 *$ & $2.208 * *$ \\
\hline & SolvRatio & $2.780 * * *$ & $2.585 * * *$ & $3.054 * * *$ & $2.943 * * *$ & $2.121 * *$ & 0.962 & 0.818 \\
\hline & $\ln ($ Age $)$ & $2.867 * * *$ & $2.687 * * *$ & $2.049 * *$ & $1.846^{*}$ & 1.563 & 1.238 & 1.217 \\
\hline \multirow[t]{5}{*}{ Trade } & $\ln (E m p l)$ & $-3.394 * * *$ & $-4.950 * * *$ & $-5.126 * * *$ & $-4.385^{* * *}$ & $-5.260 * * *$ & $-4.731 * * *$ & $-3.951 * * *$ \\
\hline & $\ln (\mathrm{LP})$ & $-5.983 * * *$ & $-2.539 * *$ & -1.146 & $-2.189 * *$ & -0.121 & -0.373 & -0.758 \\
\hline & ROS & $5.299 * * *$ & $5.645 * * *$ & $6.260 * * *$ & $5.272 * * *$ & $4.820 * * *$ & $3.761 * * *$ & $4.634 * * *$ \\
\hline & SolvRatio & $2.962 * * *$ & $2.616^{* * *}$ & $3.014 * * *$ & $2.480 * *$ & $1.767^{*}$ & $2.007 * *$ & $1.702 *$ \\
\hline & $\ln ($ Age $)$ & -0.458 & -0.334 & -0.064 & -0.250 & -0.312 & -0.735 & -0.526 \\
\hline \multirow[t]{5}{*}{ Service } & $\ln (\mathrm{Empl})$ & $-6.380 * * *$ & $-6.357 * * *$ & $-6.496 * * *$ & $-5.485 * * *$ & $-6.107 * * *$ & $-5.630 * * *$ & $-4.029 * * *$ \\
\hline & $\ln (\mathrm{LP})$ & $-9.720 * * *$ & $-7.417 * * *$ & $-5.735 * * *$ & $-5.786 * * *$ & $-5.366 * * *$ & $-4.086^{* * *}$ & $-3.406^{* * *}$ \\
\hline & ROS & $2.798 * * *$ & 1.127 & 0.798 & -0.271 & -0.204 & 1.043 & 0.344 \\
\hline & SolvRatio & -1.081 & $-1.840^{* *}$ & -1.304 & -1.400 & -1.434 & -0.077 & -0.626 \\
\hline & $\ln ($ Age $)$ & -1.298 & -0.683 & -1.021 & -0.394 & -0.133 & 0.143 & 0.524 \\
\hline
\end{tabular}

Note: $* p<0.10, * * p<0.05, * * * p<0.01$. The table reports FP statistics and their significance. A positive sign of the FP statistic implies that the distribution of the relevant variable of "continuing" firms stochastically dominates the distribution of the same variable for exiting firms

According to the FP statistics, Table 3, Box A, "continuing" firms perform better than "involuntary" exiting firms in each of the three sectors. More precisely, in line with the empirical literature (see, among the many others, Bottazzi et al. 2011; Balcaen et al. 2012; Foster et al. 2016), our findings 
suggest that "continuing" firms are older and perform better in terms of both productivity and profitability than "involuntary" exiting firms. Indeed, all FP statistics are positive and significant over the whole pre-exit period considered (2005-2011). Similarly, the solvency ratio is higher for "continuing" firms and it points to weaker financial structure of "involuntary" exiting firms which are strongly dependent on external resources. Somewhat contrary to expectations, the FP tests do not unequivocally point to a size difference between "continuing" and "involuntary" exiting firms. Namely, Table 3, Box A, shows that the significance and the sign of the FP statistics referred to $\ln ($ Empl) change across sectors as well as over time. These preliminary results do not completely diverge from the existing literature. Indeed, although many applied studies find that firms' exit probability decreases with size (e.g., Strotmann 2007; Fackler et al. 2013), some studies cannot find such evidence (e.g., Audretsch et al. 1999) and others even document a positive relationship between firms' size and their exit from the market (e.g., Bottazzi and Tamagni 2011).

Focusing on the comparison between "continuing" firms and exiting firms by M\&A (Table 3, Box B), FP statistics show that, in each of the three sectors, "continuing" firms are smaller and perform worse, in terms of productivity, than exiting firms. The evidence that larger firms are more likely to be involved in M\&A is in contrast with some studies (see, among the many others, Cefis and Marsili 2012; Wagner and Cockburn 2010), but it is in line with others, like Esteve-Pérez et al. (2010) and Masatoshi et al. (2019). In contrast to "involuntary" exit (Box A), firms exiting by M\&A (Box B) exhibit higher productivity when compared to "continuing" firms, in line with the results from Esteve-Pérez et al. (2010) and Balcaen et al. (2012), among others. Profitability displays a similar pattern to "involuntary" exit: "continuing" firms report higher level of profitability (ROS) than firms exiting through M\&A. For the service sector, this is true only in the year before exit by M\&A. The above evidence on M\&A contributes to support the view of the target, exiting firm as a company that has already achieved a certain potential (higher productivity), but that is not yet fully capable to exploit it (lower profitability). There is no significant differences between the two groups of firms in terms of solvency ratio in the service sector, while, for the manufacturing and trade sectors, the solvency ratio is higher for "continuing" firms and this points to weaker financial structure of firms exiting by M\&A. Again, in contrast to "involuntary" exit, the age distributions for firms undergoing M\&A do not show significant difference between the two groups of firms, with the exception for the manufacturing sector, where "continuing" firms are older than firms exiting through M\&A.

\subsection{Innovative vs non-innovative firms}

One of the main interest of our work is the analysis of the relationship between firms' innovativeness and survival. In order to get preliminary evidence of the impact of innovative activity on firm demography, we estimate and graphically compare the survival functions $S(t)$ using the Kaplan-Meier estimator for innovative and non-innovative firms, respectively. As for the FP tests, we consider, in turn, "involuntary" exits and exits by M\&A. ${ }^{19}$ We alternatively define innovative firms as companies with at least one granted patent and firms with at least one registered trademark.

The Kaplan-Meier estimator is a simple frequency non-parametric estimator; it does not require any exante assumption about the distribution of exit times or how regressors shift the hazard function. The estimated Kaplan-Meier survival function (i.e., the probability to survive at least up to age $t$ ) is given by:

$\widehat{S}(t)=\prod_{t_{i} \leq t}\left(1-\frac{e_{i}}{n_{i}}\right)$

where $e_{i}$ is the number of exiting firms (involuntarily or by M\&A) at age $t_{i}$ and $n_{i}$ is the number of firms at risk at $t_{i}$ (i.e., the number of firms survived up to age of $t_{i}$ years).

In the following, we estimate the Kaplan-Meier survival functions for the same observations considered in the sectoral complementary log-log regressions that we perform in Section 5. This allows us to

\footnotetext{
${ }^{19}$ See Kaplan and Meier (1958) for details on the estimator.
} 
obtain statistics that are comparable with the following empirical analysis. Also notice that when showing firms' surviving probabilities, in Figs. 1, 2, and 3, we focus on survival spells shorter than 50 years. ${ }^{20}$

Figure 1, Box A (Box B), displays the fraction of firms, in the manufacturing sector, that did not go through "involuntary" exits after a given number of years since the start of activity, distinguishing between firms with at least one granted patent (trademark) and firms without patents (trademarks).

Focusing on Box A, it is apparent that, when not controlling for other factors, firms with patents have an advantage over the group of firms without patents in terms of survival. This survival difference is rather small in the first years of activity, i.e., just a few decimal points in the first 2 years, but becomes larger and stable in the age group starting from 10 years. To provide some guidance, the share of firms that own at least one patent and survive ranges between 93.42\% (during the 10 years after their incorporation) and $70.53 \%$ (during the 50 years after their entry on the market), while for firms without patents the fractions of surviving companies are, respectively, $88.61 \%$ and $63.49 \%$.

Similarly, Fig. 1, Box B, shows that the estimated survival function for firms with at least one trademark lies above that of firms without trademarks in the manufacturing sector. In comparing Box A and $B$, note that the survival difference due to the ownership of trademarks is less pronounced than that arising from patents. In particular, in the first 2 years of activity, the survival difference is almost null, whereas it becomes larger and stable in the age group starting from 20 years.

A more statistically accurate comparison between the survival curves of different groups of firms (innovative vs non-innovative) is provided by the log rank test and the Wilcoxon-Breslow-Gehan test. The null hypothesis of both tests is that the survival functions across groups of companies are not different. Both the log-rank and the Wilcoxon-Breslow-Gehan tests, shown in Fig. 1, report a statistically significant difference in survival experience for innovative and non-innovative firms.

Consider, next, firms in the trade sector. Figure 2 suggests that firms with IP rights enjoy a survival

\footnotetext{
${ }^{20} \mathrm{We}$ exclude from the graphical comparison firms older than 50 years, which correspond to, depending on the sector, around 2 or $5 \%$ of the observations.
}

advantage. As in the manufacturing sector, even in the trade sector the advantage of firms in terms of survival due to trademarks is less pronounced than that arising from patents. The evidence from the service sector is much similar, and is not reported in the interest of space.

The non-parametric evidence on the relationship between IP rights and "involuntary" exit is in line with the existing literature. Note however that due to the specificity of the definition of "involuntary" exit, it is now possible to establish a more reliable and precise relation between proxies of innovation and their effect on firms' demography.

Finally, Fig. 3, Box A (Box B), displays the fraction of firms, in the manufacturing sector, that did not experience M\&A exit after a given number of years since the start of activity, distinguishing between firms with at least one granted patent (trademark) and firms without patents (trademarks). In comparing Figs. 1 and 3, note first that overall there is a lower probability of exit by M\&A. Similarly to "involuntary" exits, also for M\&A, firms with IP rights have a survival advantage. However, considering M\&A as exit route, the survival advantage related to trademarks is more pronounced than that arising from patents. This might suggest that for young manufacturing firms with patents, the lower risk of exit brought about by patents is, at least partly, offset by their higher appeal for acquisition. Contrarily, for firms in the trade and service sectors, it is not possible to identify any significant survival difference between innovative and non-innovative firms. ${ }^{21}$

Taken together, the analyses above suggest the existence of a different impact for patents and trademarks in increasing the survival probabilities of firms. In addition, the relative importance of the two IP instruments depends on the route to exit considered: patents are more important for increasing the survival probabilities in the case of "involuntary" exit, whereas the ownership of trademarks makes M\&A less likely to occur.

\section{Empirical analysis of firms' exit probability}

In this section, we investigate the effects of firms' characteristics on their exit probability by applying

\footnotetext{
${ }^{21}$ Graphical comparison and statistical tests are available upon request.
} 
Box A

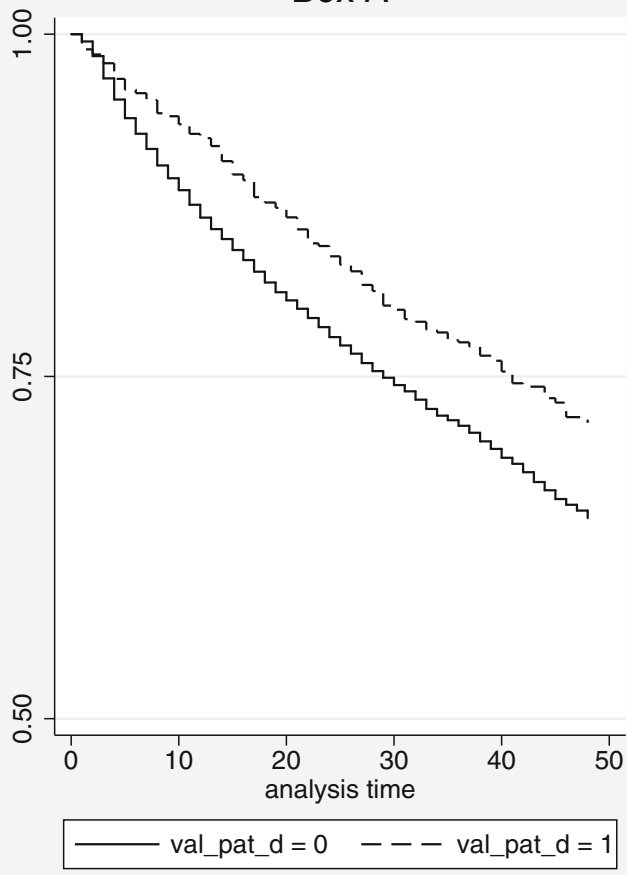

Box B

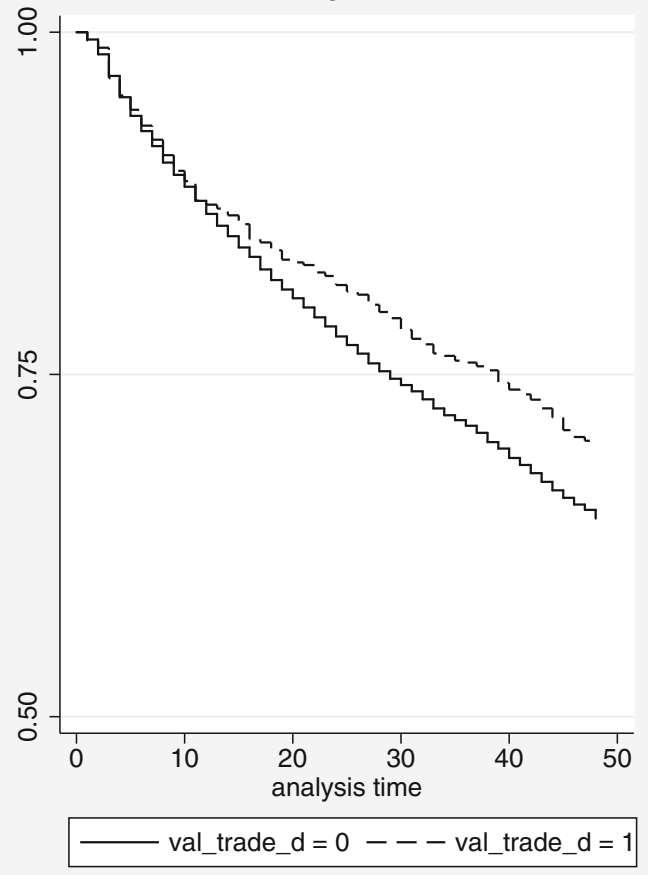

(0.0084); Wilcoxon-Breslow-Gehan test: $\chi^{2}=10.55$ (0.0012). For firms with trademarks vs firms without trademarks LogRank test: $\chi^{2}=16.11(0.0001)$; Wilcoxon-Breslow-Gehan test: $\chi^{2}=8.05(0.0046)$

employees), productivity (in log), profitability, financial stability, age, and its square (the logarithmic transformation). Moreover, we include two dummy variables, val_trade_d and val_pat_d, equal to 1 if firms own at least one granted patent or one registered trademark, respectively, and 0 otherwise. In each specification, we control for time invariant sectoral effects through a set of 2-digit industry dummy variables. We control for three geographical area dummy variables which identify firms operating in the North, Centre or South of Italy, respectively: in this way, we account for the omission of geographical specific time invariant characteristics which might bias our parameter estimates. We also include 5-year dummies (2010-2014) which allow us to account for the economic cycle and common macroeconomic factors. In order to reduce the potential endogeneity of the economic and financial variables (Empl, LP, ROS, and SolvRatio), as well as of the innovation indicators (val_trade_d and val_pat_d), these regressors 
Box A

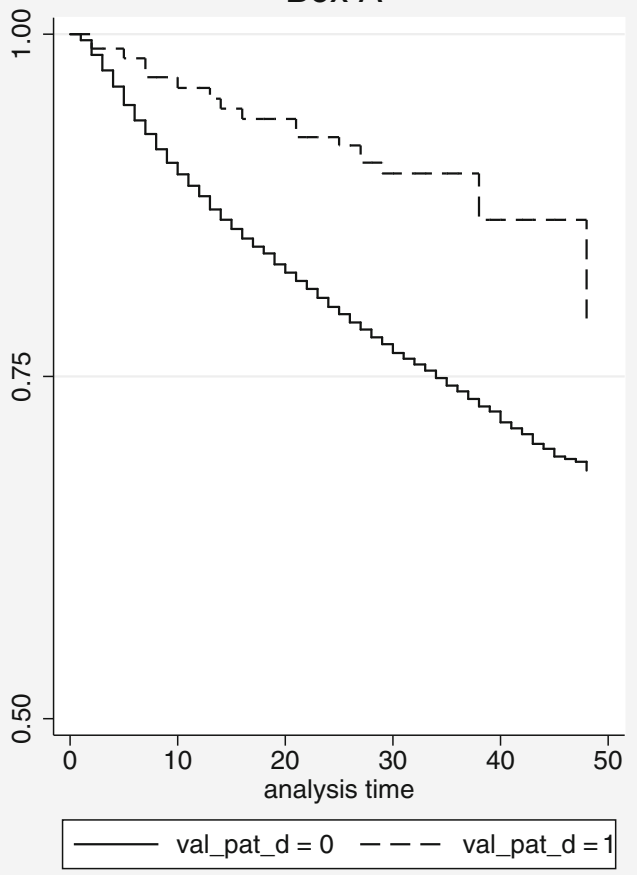

Box B

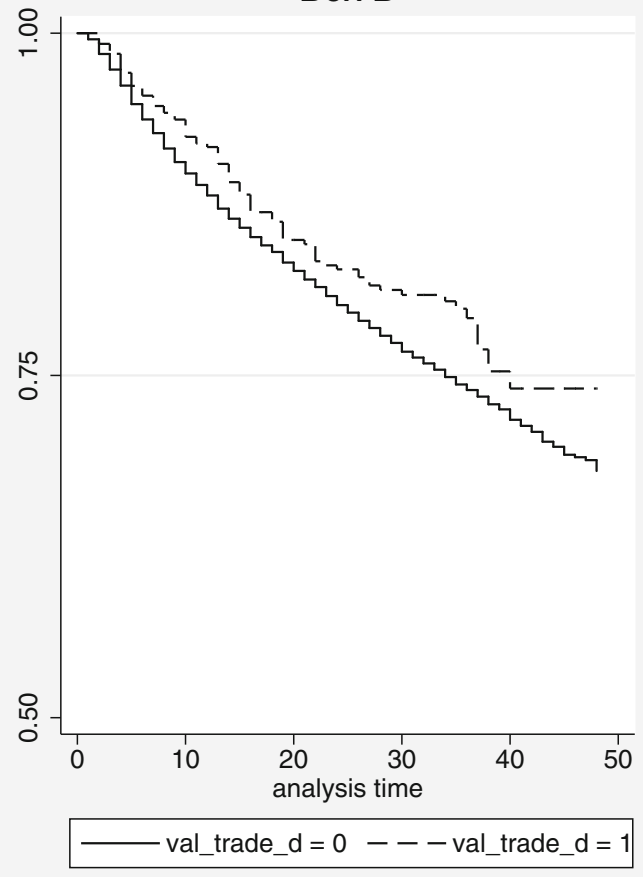

Fig. 2 Kaplan-Meier survival estimates, "involuntary" exits, trade sector, Box A patents, Box B trademarks. Analysis time is the number of years the firm survived. For firms with patents vs firms without patents Log-Rank test: $\chi 2=11.60(0.0007)$;

are lagged one period with respect to the dependent variable. ${ }^{22}$

Note that, among the regressors, we include age and its square because in principle we may expect a non-linear relationship between firms' exit probability and their age in line with empirical evidence (see, e.g, Pérez et al. 2004; Ortega-Argiles and Moreno 2007; Masatoshi et al. 2019). This non-linear effect is consistent with the "liability of newness" effect (Stinchcombe 1965) as well as with selection models (Jovanovic 1982; Ericson and Pakes 1995)

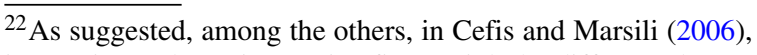
innovative and non-innovative firms might be different along a series of dimensions, above all size and age. In this respect, it is much important to include in the regressions as many controls as possible, in order to obtain unbiased estimates of the main coefficients of interest, that are, in our case, those for patents and trademarks indicators. For a similar reasoning, see Heyman (2007).
}

Wilcoxon-Breslow-Gehan test: $\chi 2=11.50$ (0.0007). For firms with trademarks vs firms without trademarks Log-Rank test: $\chi 2=3.40$ (0.0651); Wilcoxon-Breslow-Gehan test: $\chi 2=3.64$ (0.0565)

according to which age has a positive effect on survival: (infant) firms need to achieve some organizational and efficiency levels to face competitors and they go through a process of selection (inefficient firms are stranded out of the market) and learning (about their relative efficiency and market competitiveness). However, the effect of age on survival may become negative after a certain firms' age, because of the "liability of adolescence" effect (Fichman and Levinthal 1991) and the "liability of senescence" effect (Hannan 1998) according to which the probability of exit may increase with age. The reason is that when firms enter the market, they are "protected" by their initial resource endowments to face competition, but, as firms age and the environment changes, their endowments and initial choices may become inadequate; also, firms face the obsolescence of technology and products over time.

Existing empirical evidence in terms of the effects of size and age on firms' failure suggest that larger 


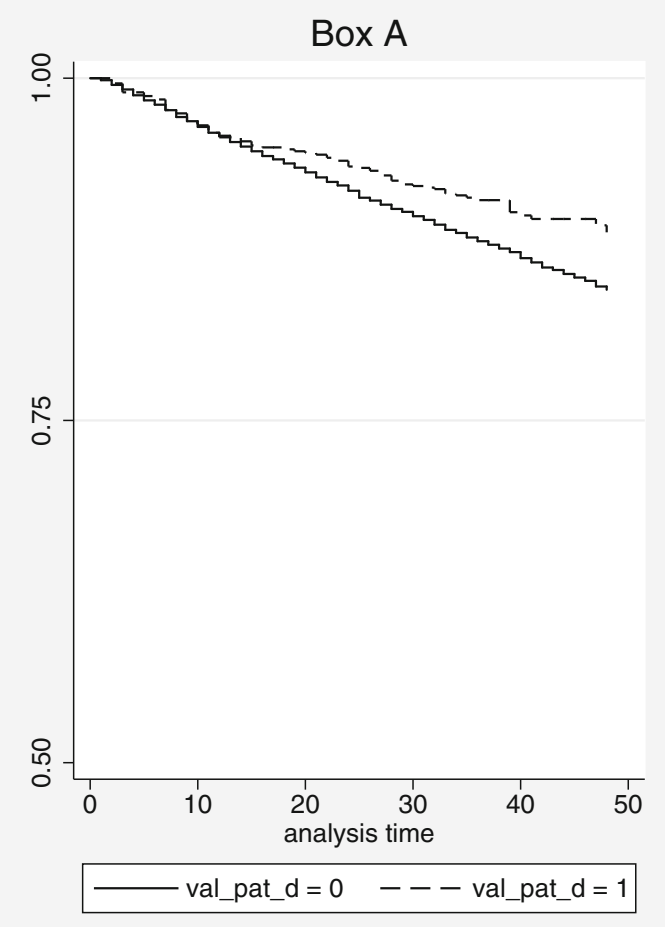

Fig. 3 Kaplan-Meier survival estimates, exits by M\&A, manufacturing sector, Box A patents, Box B trademarks. Analysis time is the number of years the firm survived. For firms with patents vs firms without patents Log-Rank test: $\chi^{2}=8.55$

and older firms have lower probability to exit than smaller and younger companies (see, e.g., Giovannetti et al. 2011; Godart et al. 2012; Fackler et al. 2013; Wagner 2013). However, some other studies report discordant results. For example, Bottazzi and Tamagni (2011) detect a positive relationship between firms' size and their probability of default and identify firms' age as a poor predictor of firms' default. Similar results in terms of firms' size impact on survival have been identified by Bottazzi et al. (2011). Other works find that the effect of firms' size and age on their probability of exit are non-linear (see, among others Strotmann 2007; Pérez et al. 2004). Thus, given the variety of results obtained in the existing literature and our preliminary results, especially for the impact of firms' size on their demographic dynamics, we do not have strong priors. Regarding the probability of M\&A, empirical evidence suggests that smaller and younger firms are more likely to be involved in

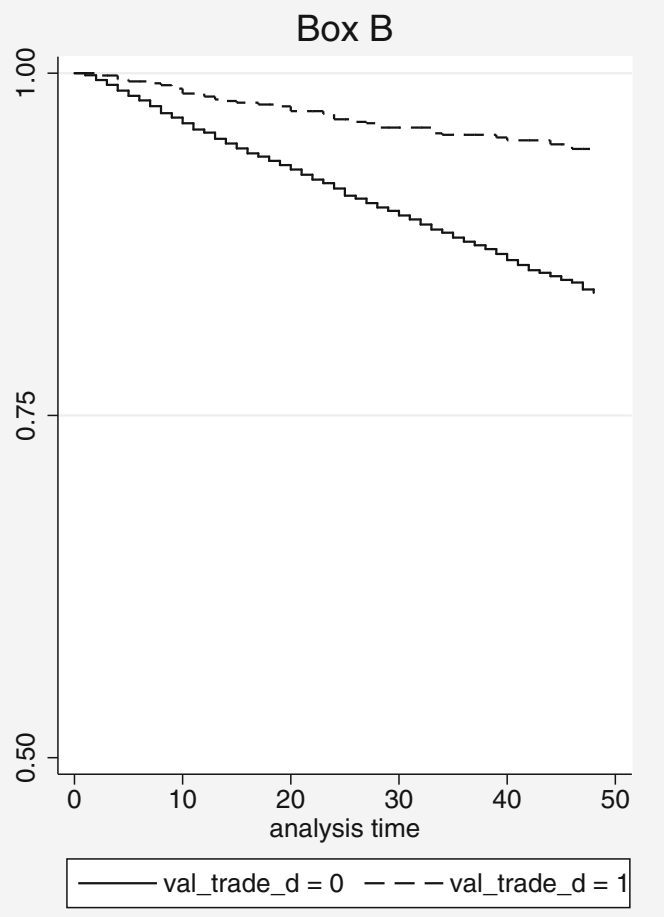

(0.0035); Wilcoxon-Breslow-Gehan test: $\chi^{2}=5.57$ (0.0183). For firms with trademarks vs firms without trademarks LogRank test: $\chi^{2}=55.08$ (0.0000); Wilcoxon-Breslow-Gehan test: $\chi^{2}=40.84(0.0000)$

M\&A (see, among the many others, Cefis and Marsili 2012; Wagner and Cockburn 2010). However, even for M\&A, there are mixed results. For example, we refer, among others, to Esteve-Pérez et al. (2010) that identify a positive relationship between firms' size and their probability to be involved in mergers with other firms, and to Wagner and Cockburn (2010) that do not find any significant relationship between firm's age and their probability of M\&A.

On the contrary, based on previous literature (see, among others, Melitz 2003; Esteve-Pérez and MañezCastillejo 2008; Bottazi et al. 2011) and on our preliminary results, we expect to identify better survival chances for firms with higher performance, measured in terms of both labor productivity and profitability. However, focusing on M\&A as mode of exit, the empirical literature, as well as our preliminary results, provides different suggestions according to the measure of performance considered. Indeed, although 
empirical works unequivocally suggest that more productive firms have a higher probability to exit by M\&A than less productive companies (see, among the many others, Esteve-Pérez et al. 2010; Balcaen et al. 2012), studies on the relationship between profitability and M\&A provide more ambiguous findings (see, among the many others, Esteve-Pérez et al. 2010; Wagner and Cockburn 2010).

Some studies identify significant effects of firms' financial characteristics (for example, proxied by leverage, solvency ratio and secured debt level) on firms' demographic dynamics (see, among others, Buddelmeyer et al. 2010; Bottazzi et al. 2011; Balcaen et al. 2012). Thus, based on previous empirical findings and on our preliminary results, we expect to find a lower probability of "involuntary" exit from the market for firms with higher solvency ratio. As for the effect of financial characteristics on M\&A, Balcaen et al. (2012), among others, find that compared to bankruptcy, the probability of voluntary exit increases with firm's financial health and, conditional on not going bankrupt, the probability of M\&A compared to voluntary liquidation decreases with firm's financial health. We may thus expect a higher likelihood of M\&A associated with higher solvency ratio.

Focusing on firms' innovative activity, the existing applied literature coherently detects a positive relationship between innovativeness and companies' survival, at least when considering failure as cause of exit. It is not easy, however, to directly compare empirical findings given the variety of measures used for innovation. In particular, some studies use R\&D expenditures (e.g., Esteve-Pérez and MañezCastillejo 2008; Esteve-Pérez 2010), others define innovative firms as companies which introduce product and/or process innovations and/or innovations in labor organization (e.g., Cefis and Marsili 2005, 2012; Giovannetti et al. 2011). ${ }^{23}$ In this work, we exploit the availability of data on trademarks and patents to study the relation between IP and survival in line with an existing strand of empirical literature

\footnotetext{
${ }^{23}$ Interestingly, Ortega-Argiles and Moreno (2007) consider the effect of innovation on survival focusing on Spanish manufacturing firms (survey data) and distinguishing between process and product innovation. They find that process innovations have a significant positive effect on the likelihood of survival; whereas product innovations appear to be a determining factor for the small and medium size firms, but not for large firms.
}

(see, among others, Jensen et al. 2008; Buddelmeyer et al. 2010; Helmers and Rogers 2010; Wagner and Cockburn 2010; Masatoshi et al. 2019).

\subsection{Empirical models}

Let us briefly outline the main characteristics of the econometric methods we apply.

In the applied literature, several studies analyze firms' exit probability by applying probit models (e.g., Helmers and Rogers 2010; Bottazi et al. 2011; Bottazzi and Tamagni 2011). This estimation method, however, belongs to the conventional cross-section techniques that estimate the unconditional average probability of occurrence of an event during the sample period. Thus, in order to obtain estimates which account for whether and, if so, when events occur, we estimate complementary log-log models, i.e., discretetime hazard model (for applications to the context of firm survival, see Cefis and Marsili 2012; Godart et al. 2012; Masatoshi et al. 2019). ${ }^{24}$ In this way, we estimate the probability that a firm exits in interval $t$ (age $t$ ), conditional on its survival up to the beginning of this interval and given the independent variables included in the regression specifications. In particular, we opt for discrete, instead of continuous, time hazard models, because, by construction, our data identify the year of firms exit but not the exact date of the exit (thus, exits are grouped into discrete intervals of time).

In the complementary log-log models, the probability that a firm exits in interval $t$ (i.e., at age $t$ ), conditional on its survival up to the beginning of this interval and given the independent variables, is given by the following equation:

$h_{t}\left(X_{i, t-1}\right)=1-\exp \left\{-\exp \left(X_{i, t-1}^{\prime} \beta+\theta(t)\right)\right\}$

where $t$ is the age of the firm, $\theta(\mathrm{t})$ is the baseline hazard function, and $X_{i, t-1}$ is a vector of regressors and controls. We use a quadratic specification for the pattern of duration dependence. Thus, we enter firms' age and their square as covariates in the regressions.

\footnotetext{
${ }^{24}$ Refer to Esteve-Pérez et al. (2013) for an application of complementary log-log models for firms' survival in the context of international trade relationship.
} 
In order to test for possible biases due to the effects of unobserved individual heterogeneity, for each exit mode, and each sector, we estimate the complementary $\log -\log$ model, with a frailty term, that allows us to control for unobserved individual heterogeneity (see among the others, Jenkins 2004), and we refer to the following specification:

$h_{t}\left(X_{i, t-1}\right)=1-\exp \left\{-\exp \left(X_{i, t-1}^{\prime} \beta+\theta(t)+u_{i}\right)\right\}$

where we include individual random effects by means of an error term, $u_{i}=\log \left(v_{i}\right)$, that is assumed to be normally distributed with 0 mean and variance $\sigma^{2}$.

Then, we test, through a Likelihood-ratio test, the null hypothesis that the "rho" statistic (i.e., the ratio of the heterogeneity variance to one plus the heterogeneity variance) is statistically equal to zero. Failure to reject the null hypothesis, suggest that unobserved heterogeneity does not affect the estimated coefficients, and the complementary log-log model without the frailty term is then the preferred specification. ${ }^{25}$

\subsection{Results}

Table 4 shows the sectoral complementary log-log estimated coefficients for both models with and without the frailty term (i.e., unobserved individual heterogeneity), considering, in turn, firms' "involuntary" exits (Box A) and exits by M\&A (Box B). Taking into account evidence from the test on the unobserved individual heterogeneity, we comment results obtained from specifications with the frailty term only when the "rho" statistics are statistically different from zero; differently, comments refer to estimates of the complementary log-log models that do not account for unobserved individual heterogeneity. Note that a posi-

\footnotetext{
${ }^{25}$ In order to account for unobserved individual heterogeneity, on top of a frailty term normally distributed, we alternatively estimated the complementary log-log models with Gamma distributed frailty term and, similarly to Zhang (2003), the models with non-parametric unobserved individual heterogeneity. In the paper we only show results for the complementary log-log models with a frailty term normally distributed. Other results are in line with those shown and are available upon request.
}

tive coefficient associated with a regressor implies that the hazard rate of firm exit increases (that is, the firm probability of survival decreases) with higher value of that explanatory variable, while the opposite holds if a negative coefficient is associated with an independent variable.

In our analysis, we consider two different types of exit, "involuntary" exit and M\&A; moreover, we verify whether the relationship between firms' characteristics and their survival differ across sectors (manufacturing, trade, and service sectors). Note that most of previous studies focused on manufacturing only.

As shown in Table 4, Boxes A and B, the effect of size on firms' exit changes depending on the route of exit and, in some cases, on the sector considered in the analysis. In particular, focusing on "involuntary" exit (Box A), we find a positive and significant relationship between size and the hazard rate of exit for firms in the manufacturing sector, while the relationship turns out to be negative or not significant for firms in the trade and service sectors, respectively. Our results for the manufacturing firms are in line with Bottazzi and Tamagni (2011) that analyzing a large sample of Italian firms shows how the probability of default increases with size. While, only for firms in the trade sector, our parametric estimates validate the hypothesis of "liability of smallness" (Stinchcombe 1965). This advantage might be explained by the fact that bigger companies are less financially constrained, face lower difficulties in recruiting higher skilled workers, and have cost advantages compared to smaller firms. As for M\&A (Box B), independently of the sector of activity, in line with Esteve-Pérez et al. (2010) and Masatoshi et al. (2019), we identify a positive relationship between firms' size and the M\&A probability. Among sectors, estimates reveal that the positive relationship between size and exit by M\&A seems to be more pronounced in the trade sector. ${ }^{26}$

\footnotetext{
${ }^{26}$ The LR tests on the unobserved individual heterogeneity do not allow us to unequivocally prefer one estimation method for all of our estimates (complementary log-log models without and with frailty). Thus, in order to compare coefficients across sectors obtained by applying the same econometric technique, we focus on estimates obtained using complementary log-log without frailty (i.e., cloglog instead of xtcloglog). The two-sided and one-sided Wald tests that we use, in order to statistically test the differences between coefficients across sectors, are available upon request.
} 
Table 4 Maximum Likelihood estimates for discrete time hazard model

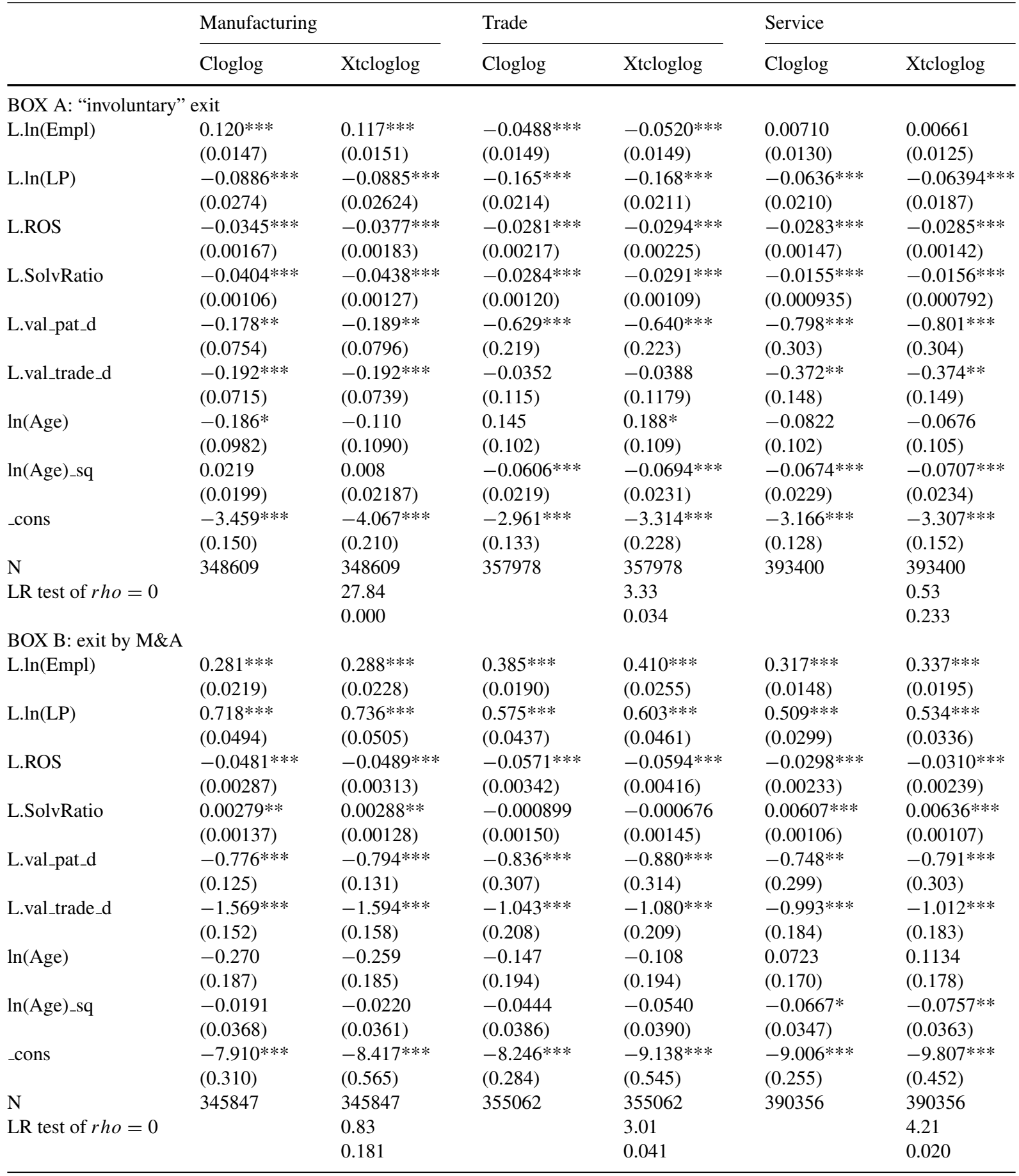

Note: Coefficients and (Robust) Standard errors in parentheses (for the models without the frailty term). Columns labeled $x t c l o l o g$ reports estimates for the complementary log-log models with the frailty term. Statistical significance is reported as: $* p<0.10$, $* * p<0.05, * * * p<0.01$. Estimates include a full set of geographical area, year and Nace Rev. 2 dummy variables. For the LR test, we report chibar $^{2}$ and the corresponding Prob $\geq$ chibar $^{2}$ 
Regarding firms' performance, both in terms of productivity and profitability, we find strongly significant effects on firms' demographic dynamics. Indeed, in line with the relevant literature (see, e.g., Melitz 2003; Esteve-Pérez and MañezCastillejo 2008; Bottazzi et al. 2011), our findings imply that higher performance reduce the firm's probability of "involuntary" exit. Focusing on exit by M\&A, we find that higher productivity increases the probability of exit by acquisition, whereas the opposite is true for profitability. Both results are in agreement with the non-parametric evidence of the FP test and thus confirm the view of M\&A as a much different exit route. Higher performance can indeed represent a sign of appeal for an acquisition. Estimates show some difference among sectors. In particular, when we consider the probability of "involuntary" exit, the impact of productivity is more relevant for firms in the trade sector, while the effect of profitability is higher for firms in the manufacturing sector. The opposite holds when we focus on the probability of exit by M\&A.

As for the firms' financial structure, coherently with previous empirical results (e.g., Buddelmeyer et al. 2010; Bottazzi et al. 2011; Balcaen et al. 2012), our work identifies a negative and significant correlation between firms' solvency ratio and their probability of "involuntary" exit. However, differently from our non-parametric results, estimates suggest a positive and significant relationship between firms' solvency ratio and the likelihood of exit through M\&A (with the exception for firms in the trade sector), again suggesting that exit by M\&A should not be assimilated to business failure. For firms in the manufacturing sector, we find the highest negative impact of firms' solvency ratio on their probability of "involuntary" exit, while the lowest effect is found for firms in the service sector. Contrarily, focusing on exit through M\&A, the positive impact of firms' solvency ratio is higher for firms in the service sector than for firms in the manufacturing sector.

Focusing on the effect of age, we find that only for firms in the trade sector, the hazard of "involuntary" exit first increases and then decreases. A non-linear effect is in line with the results obtained by Masatoshi et al. (2019) on a sample of Japanese new firms. In the service sector, for both "involuntary" exit and M\&A, we find that the effect of firms' age on exit becomes negative after a certain age.

Regarding the impact of firms' innovative activity on their demographic dynamics, our estimates suggest that firms' IP reduces the probability of exit from the market. When we consider "involuntary" exit (Box A), the effect of patents and trademarks is rather similar in the manufacturing sector, whereas, now that we are controlling for other regressors, patents appear more relevant for survival than trademarks in the trade and service sectors. Moreover, the negative impact of patents on "involuntary" exit is more pronounced in the trade and service sectors than in the manufacturing sector, while the negative effect of trademarks does not significantly differ across firms in the service and manufacturing sectors.

Finally, the impact of patents and trademarks on M\&A is much similar across sectors. In particular, the coefficients for firms with at least one granted patent is $-0.776,-0.880$, and -0.791 , for firms in the manufacturing, trade, and service sector, respectively, which correspond to hazard ratios of 0.469 , $0.410,0.453 .{ }^{27}$ Hence, the hazard of exiting is $53 \%$, $58 \%$, and 55\% lower for firms with patents than for firms without patents. ${ }^{28}$ Similarly, the probability of exit is $79 \%, 66 \%$, and $63 \%$ lower for firms with trademarks than for firms without trademarks, in the manufacturing, trade and service sectors, respectively. Tests on coefficients point out only one quantitative difference: the negative impact of having trademarks on the M\&A probability is higher for firms in the manufacturing sector than for firms in the other sectors.

In comparing the effects of patents and trademarks between "involuntary" exit and M\&A, a striking reg-

\footnotetext{
${ }^{27}$ As suggested in Godart et al. (2012), starting from the estimated coefficient associated with a regressor, $\beta$, the corresponding hazard ratio can be obtained as $\exp (\beta)$.

${ }^{28}$ The hazard of exit is obtained as $1-\exp (\beta)$.
} 
ularity emerges across all sectors. Indeed, if patents appear overall more relevant against "involuntary" exit, the opposite is true for M\&A, where trademark is the IP variable that has the larger effect. Although we cannot directly compare coefficients across different regressions ("involuntary" exit and M\&A), the change in the relative magnitude of the coefficients accounting for patent and trademark dummies, is in line with the suggestion emerging from the Kaplan-Meier nonparametric analysis, according to which the relevance and appeal of the patent portfolio in the eye of the acquiring firm, might lessen the effect of protection against exit exerted by patents under other modes of exit.

\section{Conclusion}

This study investigates the impact of patents and trademarks, as well as other firm-level characteristics, on different exit modes: "involuntary" and M\&A.

Our work contributes to the previous literature in several ways. We enrich the existing scant empirical evidence on firms' dynamics in the post-crisis period; we analyze the impact of firms' innovation activity; we provide a more rigorous definition of "involuntary" exit; and, finally, we are able to detect some industrial specificities by distinguishing among firms operating in the manufacturing, service, and trade sectors. As for the impact of innovation activity, we use data on the granted patents and registered trademarks owned by firms to proxy their innovativeness. As Schautschick and Greenhalgh (2016) state, IP rights have been extensively used to capture the ability of firms to provide new and technologically advanced products, as well as the aptitude of companies to supply a wide variety of products and services. Moreover, the availability of information on both trademarks and patents makes it possible for us to explore the differences in the effects of two types of IP. For example, as suggested by Jensen et al. (2008) patents can be used to proxy for high-risk (new to the market) innovations, whereas trademarks can proxy for lowrisk (new to the firm) innovations. Furthermore, the consideration of both patents and trademarks may help capture innovations in both the manufacturing and service sectors, as observed by Buddelmeyer et al. (2010) and Schautschick and Greenhalgh (2016). Studies that only consider patents or R\&D expenditures, the most common proxies for innovation, might under-represent the innovative propensity of firms in the service sector, where companies rarely patent their new services and often do not perform formal R\&D activity. Conversely, trademarks are used by firms in both the manufacturing and service sectors.

One of the main contributions to the empirical literature on firms' survival is the sharp distinction we can draw between exit modes. Indeed, thanks to the availability of data on administrative procedures, we can identify "involuntary" exits and exits by M\&A. Thus, our indicator of "involuntary" exits is less spurious than those often used in most of the existing empirical literature.

Interesting results emerge from the effects of firm characteristics on different modes of exit and across sectors of activity. Performance, for instance, as proxied by productivity, shows a positive effect in protecting against "involuntary" exit, whereas a high productivity is related to a higher likelihood of exit by M\&A, as it might be an element of appeal in a firm targeted for acquisition. Size, as proxied by number of employees, has a positive impact on the probability of exit by $M \& A$ in manufacturing, trade and services; in contrast, the effect of size on "involuntary" exit differs across sectors: it is positive for manufacturing firms, negative for firms in the trade sector, and not significant for firms in the service sector. The importance of patents and trademarks in affecting the probability of exit shows some specific patterns across sectors. For instance, trademarks do not appear to play any role in preventing "involuntary" exit in the trade sector; as for patents, their negative impact on "involuntary" exit is greater in the trade and service sectors than in the manufacturing sector. In comparing the effects of patents and trademarks across exit modes, however, some regularities across sectors also emerge. If, overall, patents appear more significant against "involuntary" exit, the opposite is true for M\&A, where trademarks are the IP instrument with the largest effect.

Our empirical analysis faces a twofold limitation. The first depends on our definition of innovative firms based on IP: we do not account for 
innovative activities that are not related to patents and trademarks. As Buddelmeyer et al. (2010) note, however, this weakness mainly depends on firms' balance sheet data which do not make it possible to precisely identify $R \& D$ expenditures for all firms. Moreover, data from the business register do not include information on alternative measures of innovation (e.g., it is not possible to identify firms which introduce product, process, and/or organizational innovations). The second weakness of our work, common to most of the related applied studies, is the impossibility to identify a clear causal relationship between firms' indicators and their survival. This is, at least in part, mitigated by accounting for unobserved heterogeneity in our regressions, as well as by including lagged independent variables in each regression.

\section{Appendix A: Data Appendix}

This technical appendix describes, in brief, the building process leading to the final set of data employed in the empirical analysis. Furthermore, in order to assess the reliability of the dataset, we also compare the values of the variables we are mostly interested in with those computed on other available sources. For further details on the construction of the dataset, we refer to Grazzi et al. (2018).

BvD AIDA contains detailed information on Italian limited liability firms. This category of firms, to comply with law, must deposit the balance sheet to the local Chamber of Commerce, this is why we consider it as the virtual universe of active limited liability firms. Users can access BvD AIDA data either online through a subscription or via physical media. BvD AIDA provides the standard variables from the balance sheet as well as the variable "year of incorporation," which is used to compute the age of the firm; and, most importantly, the variable "pending administrative procedures" that we use to categorize the mode of firm exit. BvD also provides a unique firm identification number, so that it is possible to link to the same firm, information coming from other BvD sources. In this respect, we employed BvD Amadeus to extract information on firms' patenting and trademarking activities.

In the following, we provide a comparison between the dataset we assembled from the BvD sources and a different, yet official source as INFOCAMERE (Infocamere 2019). ${ }^{29}$

INFOCAMERE data provide information on all economic sectors and on the geographical distribution of firms. We focus on the period 2010-2014 and, in order to have a more accurate comparison, we only include joint stock companies, limited partnerships with shares, and limited liability companies. As reported in Table 5, firms included in AIDA represent around $71 \%$ of the population according to INFOCAMERE dataset. ${ }^{30}$ As suggested by both INFOCAMERE press-office and BvD division, the difference on the coverage of the two datasets is mostly due to the fact that AIDA only includes firms appearing in the register of companies that actually deposit their balance sheets to the Italian Chambers of Commerce. On the other hand, INFOCAMERE dataset covers all firms showing up in the register of companies irrespectively of their status and of whether or not they handed in their balance sheets. Moreover, we exclude from our dataset those companies that, although not going through any administrative procedures, have been deleted from the AIDA dataset because they did not report their balance sheets in the last 5 years. Table 5 suggests that the sectoral distribution of firms in the AIDA dataset turns out to be very similar to the distribution of firms included in the INFOCAMERE data. In particular, in both sources, about $16 \%$ of firms operates in the manufacturing sectors, about $20 \%$ in the trade sectors and about $23 \%$ in the service sectors. ${ }^{31}$ Thus, we can conclude that our dataset built on $\mathrm{BvD}$ sources is much representative of the actual distribution of Italian firms' across sectors.

The complete list of sectors employed for Table 5 is reported in Table 6.

\footnotetext{
${ }^{29}$ INFOCAMERE is the company of the Italian Chambers of Commerce that takes care of processing the data coming from the balance sheet of limited liability firms. Movimprese is a report on firms' death and birth provided by INFOCAMERE every quarter.

${ }^{30}$ In Tables 5 and 7 , in order to identify the coverage of the AIDA dataset with respect to INFOCAMERE data, we account for all available observations, thus also including firms which did not provide information on their economic sector.

${ }^{31}$ In both INFOCAMERE and AIDA dataset, firms operating in the manufacturing, trade and service sectors (excluding firms in Nace Rev. 2 Sections: D, E, F, I, K, L, O, T, and U) represent about the $60 \%$ of the total number of firms.
} 
Table 5 Comparison of AIDA and INFOCAMERE firm-level data

\begin{tabular}{|c|c|c|c|c|c|c|c|c|}
\hline \multirow[b]{2}{*}{ Year } & \multicolumn{2}{|l|}{ All firms } & \multicolumn{2}{|c|}{ Manufact. } & \multicolumn{2}{|l|}{ Trade } & \multicolumn{2}{|c|}{ Service } \\
\hline & (I) & (II) & (III) & (IV) & $(\mathrm{V})$ & (VI) & (VII) & (VIII) \\
\hline 2010 & 929,340 & 72.30 & 16.50 & 16.48 & 21.61 & 19.69 & 22.54 & 22.37 \\
\hline 2011 & 953,949 & 70.30 & 16.13 & 16.26 & 21.58 & 19.74 & 22.65 & 22.53 \\
\hline 2012 & 966,141 & 69.30 & 15.83 & 16.11 & 21.63 & 19.87 & 22.86 & 22.78 \\
\hline 2013 & 982,943 & 69.53 & 15.59 & 15.94 & 21.84 & 20.06 & 23.13 & 23.06 \\
\hline 2014 & $1,008,451$ & 70.78 & 15.34 & 15.61 & 21.97 & 20.27 & 23.44 & 23.40 \\
\hline
\end{tabular}

Note: Columns reports, respectively: (I) the number of active limited liability companies in INFOCAMERE; (II) the percentage coverage in AIDA; the share of firms in manufacturing sectors in INFOCAMERE (III) and AIDA (IV); the share of firms in trade sector in INFOCAMERE (V) and in AIDA (VI); the share of firms in service sector in INFOCAMERE (VII) and in AIDA (VIII). Firms in the following service sectors are not included: (Nace Rev. 2) Sections: D, E, F, I, K, L, O, T, and U. For the description of sectors see Table 6

Table 6 Nace Rev 2: Sections

\begin{tabular}{|c|c|c|}
\hline Macrosector & Nace Rev 2 codes & Definitions \\
\hline \multirow[t]{4}{*}{ Manuf. } & $\mathrm{C}$ & Manufacturing \\
\hline & $\mathrm{D}$ & Electricity, gas, steam and air conditioning supply \\
\hline & $\mathrm{E}$ & Water supply; sewerage, waste management and remediation activities \\
\hline & $\mathrm{F}$ & Construction \\
\hline Trade & $\mathrm{G}$ & Wholesale and retail trade; repair of motor vehicle and motorcycles \\
\hline \multirow[t]{2}{*}{ Service } & $\mathrm{H}$ & Transportation and storage \\
\hline & I & Accommodation and food service activities \\
\hline \multirow[t]{3}{*}{ Service } & $\mathrm{J}$ & Information and communication \\
\hline & $\mathrm{K}$ & Financial and insurance activities \\
\hline & $\mathrm{L}$ & Real estate activities \\
\hline Service & M & Professional, scientific and technical activities \\
\hline \multirow[t]{2}{*}{ Service } & $\mathrm{N}$ & Administrative and support service activities \\
\hline & $\mathrm{O}$ & Public administration and defence; compulsory social security \\
\hline Service & $\mathrm{P}$ & Education \\
\hline Service & Q & Human health and social work activities \\
\hline Service & $\mathrm{R}$ & Arts, entertainment and recreation \\
\hline \multirow[t]{4}{*}{ Service } & $\mathrm{S}$ & Other service activities \\
\hline & $\mathrm{T}$ & Activities of households as employers; undifferentiated goods -and \\
\hline & & service- producing activities of households for own use \\
\hline & $\mathrm{U}$ & Activities of extraterritorial organizations and bodies \\
\hline
\end{tabular}

Note: From section C, we exclude firms in the tobacco and repair industry, respectively code 12 and 33 from Nace Rev. 2. ISTAT does not provide Industrial product price index for these sectors for the period of analysis. Gray background refers to Sections of the NACE not included in the analysis on the AIDA sample 
As we did for the sectoral distribution of firms, we now compare the coverage of the dataset we assembled with respect to information reported by INFOCAMERE for entrants, exiting, and active firms. It is worth noticing that INFOCAMERE data do not distinguish between modes of exit. In particular, INFOCAMERE considers a firm as exited if it underwent any administrative procedure. Accordingly, the only way to provide an accurate comparison is adopting the same definition as INFOCAMERE. Table 7 reports the comparison for the period 2010-2014.

In the dataset that we assembled, the entry rate is slightly higher than that reported by INFOCAMERE (9.229\% vs $8.811 \%$ on average over the period 2010 2014). This small difference could be explained by the different number of active firms included in the two datasets. As for the exit rate, they are very similar. In particular, for the period 2010-2012, the percentage of exits is higher in AIDA than in INFOCAMERE, while in more recent years the opposite is true. Again, this small difference could be due to the different number of active firms and to the different method to identify the year of exit.

Finally, Table 8 reports the administrative procedures leading to "involuntary" firm exit. Unfortunately, there are no available alternative sources of data for comparison.

We next turn to provide some details on the coverage of IP activities of Italian firms in our sample (in the interest of space, tables are available upon request). We are not aware of a close match to our work for comparison. There have been attempts to link patent data to firm-level data for Italian companies, but they generally cover only large firms, whereas our interest here is gaining a perspective on the (virtual) universe of limited liability firms.

The number of firms having at least one registered trademark increased during the period of interest (from around 12,000 in 2010 to more than 16,000 in 2014), while the number of firms holding at least one granted patent is more stable over the years (it slightly decreases from around 9700 firms in 2010 to around 8400 in 2014). Also, notice that there are more firms with trademarks than with patents and that the largest number of firms owning IP is in the manufacturing sector.

Data show that, in absolute figures, the highest number of firms with trademarks or patents are micro or small ones. This is of course the result of the highly skewed size distributions of Italian firms, so that, even if a large company is more likely to hold IP than a small one, this does not show up when looking at absolute numbers.

Data reveal that, as expected, in absolute figures, the highest number of firms with IP rights is concentrated in the manufacturing sectors. In all the economic sectors (primary, manufacturing and service), the number of firms with registered trademarks is larger than the number of firms with granted patents. Moreover, the number of firms owning at least one registered trademark increases during the period of investigation; while it is not the same for the frac-

Table 7 Comparison between AIDA and INFOCAMERE datasets: Firms' entry and exit

\begin{tabular}{|c|c|c|c|c|c|c|}
\hline \multirow[b]{2}{*}{ Year } & \multicolumn{2}{|c|}{ Number of active firms } & \multicolumn{2}{|c|}{$\%$ of entrants } & \multicolumn{2}{|c|}{$\%$ of exits } \\
\hline & (AIDA) & (INFOC.) & (AIDA) & (INFOC.) & (AIDA) & (INFOC.) \\
\hline 2010 & 671,926 & 929,340 & 10.330 & 9.504 & 6.698 & 5.288 \\
\hline 2011 & 670,600 & 953,949 & 9.203 & 8.464 & 6.938 & 5.409 \\
\hline 2012 & 669,578 & 966,141 & 8.439 & 7.901 & 6.531 & 5.657 \\
\hline 2013 & 683,430 & 982,943 & 8.954 & 8.543 & 5.161 & 5.410 \\
\hline 2014 & 713,807 & $1,008,451$ & 8.842 & 9.160 & 4.021 & 5.154 \\
\hline
\end{tabular}

Note: Columns II and III show the total number of active firms (limited liability companies) in AIDA and INFOCAMERE data, respectively; columns IV and V display the share of entrants. Columns VI and VII exhibit the share of exiting firms 


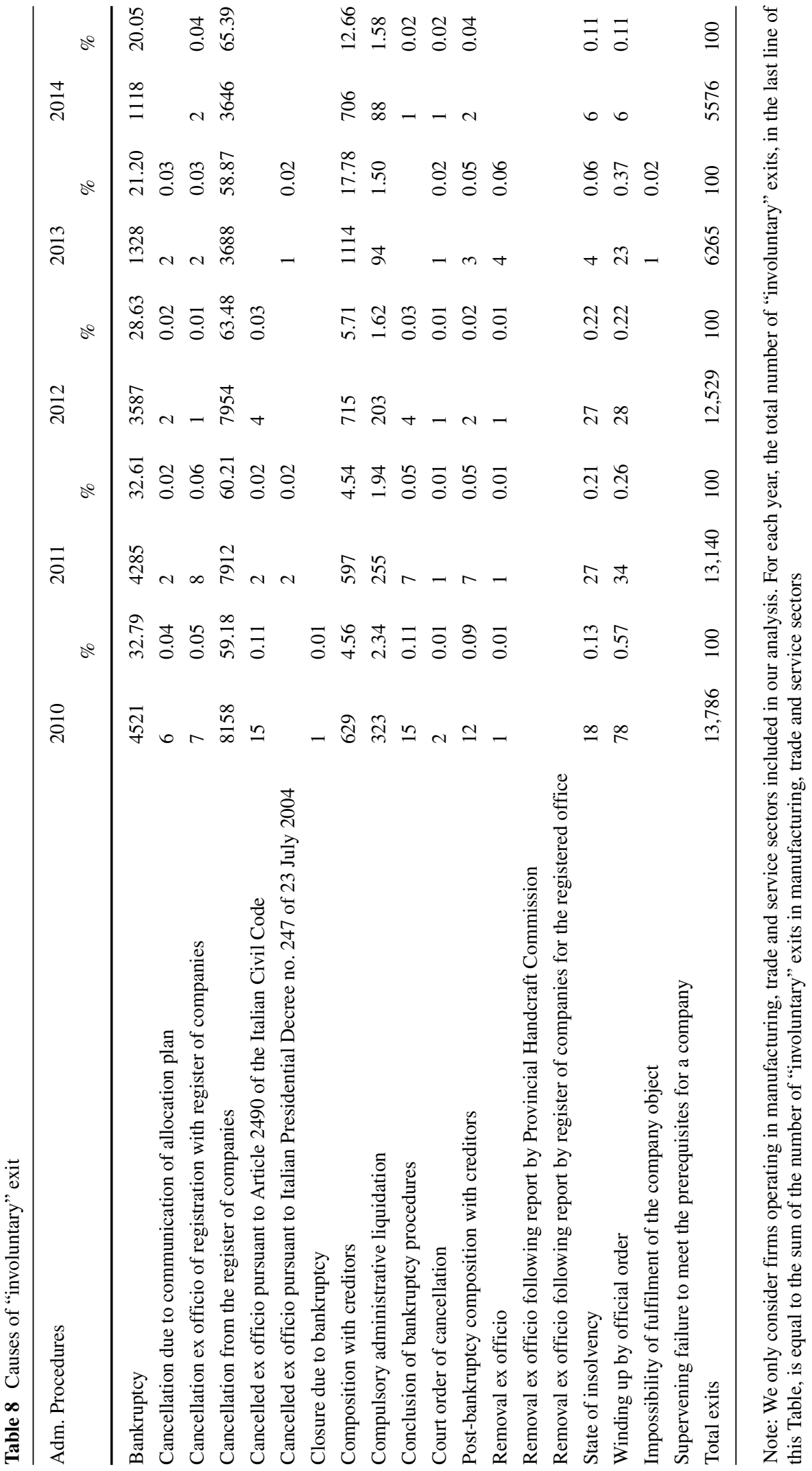


tion of firms owning at least one granted patent. Thus, at least in Italy, trademark is the most diffused instrument of IP protection.

Acknowledgements We thank the participants to the "Organizzazione e strategie innovative d'impresa in economia aperta" workshop (Forlì, June 2016), the EMAEE Strasbourg (May 2017), the Italian Society of Economists (SIE) conference (Cosenza, October 2017), the Bank of Italy, CEPR-EIEF Conference (Rome, December 2018). We are grateful to Roberto Susanna (Infocamere) and to Bureau van Dijk for their technical assistance at various stages. We are also indebted to Carlo Altomonte, Daniele Moschella, Lorenzo Zirulia and two anonymous referees for insightful comments. All remaining errors are our own.

Funding Open access funding provided by Università Cattolica del Sacro Cuore within the CRUI-CARE Agreement. This work received financial support within the project "ORGANIMPRE" founded by the Fondazione Cassa dei Risparmi di Forlì and by the University of Bologna under the Alma Idea 2017 scheme. This work has also been partly supported by the European Commission under the H2020 program, Grant Agreement 822781 (GROWINPRO).

Open Access This article is licensed under a Creative Commons Attribution 4.0 International License, which permits use, sharing, adaptation, distribution and reproduction in any medium or format, as long as you give appropriate credit to the original author(s) and the source, provide a link to the Creative Commons licence, and indicate if changes were made. The images or other third party material in this article are included in the article's Creative Commons licence, unless indicated otherwise in a credit line to the material. If material is not included in the article's Creative Commons licence and your intended use is not permitted by statutory regulation or exceeds the permitted use, you will need to obtain permission directly from the copyright holder. To view a copy of this licence, visit http:// creativecommons.org/licenses/by/4.0/.

\section{References}

Amendola, A., Ferragina, A.M., Pittiglio, R., Reganati, F., et al. (2012). Are exporters and multinational firms more resilient over a crisis? first evidence for manufacturing enterprises in Italy. Economics Bulletin, 32(3), 1914-1926.

Audretsch, D.B., Santarelli, E., Vivarelli, M. (1999). Start-up size and industrial dynamics: some evidence from italian manufacturing. International Journal of Industrial Organization, 17(7), 965-983. https://doi.org/10.1016/S01677187(98)00002-2.

Balcaen, S., Manigart, S., Buyze, J., Ooghe, H. (2012). Firm exit after distress: differentiating between bankruptcy, voluntary liquidation and M\&A. Small Business Economics, 39(4), 949-975. https://doi.org/10.1007/s11187-011-9342-7.

Block, J.H., Fisch, C.O., Hahn, A., Sandner, P.G. (2015). Why do SMEs file trademarks? insights from firms in innovative industries. Research Policy, 44(10), 1915-1930. https://doi.org/10.1016/j.respol.2015.06.007.

Børing, P. (2015). The effects of firms' r\&d and innovation activities on their survival: a competing risks analysis. Empirical Economics, 49(3), 1045-1069. https://doi.org/ 10.1007/s00181-014-0901-z.

Bottazzi, G., \& Tamagni, F. (2011). Big and fragile: when size does not shield from default. Applied Economics Letters, 18(14), 1401-1404. https://doi.org/10.1080/13504851. 2010.539 .

Bottazzi, G., Grazzi, M., Secchi, A., Tamagni, F. (2011). Financial and economic determinants of firm default. Journal of Evolutionary Economics, 21(3), 373-406. https://doi.org/10.1007/s00191-011-0224-6.

Brito, D. (2003). Preemptive mergers under spatial competition. International Journal of Industrial Organization, 21(10), 1601-1622. https://doi.org/10.1016/S0167-7187(03)00048-1.

Buddelmeyer, H., Jensen, P.H., Webster, E. (2010). Innovation and the determinants of company survival. Oxford Economic Papers, 62(2), 261-285. https://doi.org/10.1093/ oep/gpp012.

Bureau van Dijk (2019a). Aida database. [online]. Available at: https://aida.bvdinfo.com.

Bureau van Dijk (2019b). Amadeus database. [online]. Available at: https://amadeus.bvdinfo.com.

Carreira, C., \& Teixeira, P. (2016). Entry and exit in severe recessions: Lessons from the 2008-2013 Portuguese economic crisis. Small Business Economics, 46(4), 591-617. https://doi.org/10.1007/s11187-016-9703-3.

Cefis, E., \& Marsili, O. (2005). A matter of life and death: innovation and firm survival. Industrial and Corporate Change, 14(6), 1167-1192. https://doi.org/10.1093/icc/dth081.

Cefis, E., \& Marsili, O. (2006). Survivor: The role of innovation in firms' survival. Research Policy, 35(5), 626-641. https://doi.org/10.1016/j.respol.2006.02.006.

Cefis, E., \& Marsili, O. (2012). Going, going, gone. Exit forms and the innovative capabilities of firms. Research Policy, 41(5), 795-807. https://doi.org/10.1016/j.respol.2012. 01.006 .

Coad, A. (2014). Death is not a success: Reflections on business exit. International Small Business Journal, 32(7), 721-732. https://doi.org/10.1177/0266242612475104.

Colantone, I., Coucke, K., Sleuwaegen, L. (2015). Low-cost import competition and firm exit: evidence from the EU. Industrial and Corporate Change, 24(1), 131-161. https://doi.org/10.1093/icc/dtu008.

de Rassenfosse, G., \& Jaffe, A.B. (2018). Econometric evidence on the depreciation of innovations. European Economic Review, 101, 625-642. https://doi.org/10.1016/j. euroecorev.2017.11.005.

Delmar, F., McKelvie, A., Wennberg, K. (2013). Untangling the relationships among growth, profitability and survival in new firms. Technovation, 33(8), 276-291. https://doi.org/ 10.1016/j.technovation.2013.02.003.

Elfenbein, D.W., \& Knott, A.M. (2015). Time to exit: Rational, behavioral, and organizational delays. Strategic Management Journal, 36(7), 957-975. https://doi.org/10.1002/smj. 2262.

Ericson, R., \& Pakes, A. (1995). Markov-perfect industry dynamics: A framework for empirical work. The Review of Economic Studies, 62(1), 53-82. https://doi.org/10.2307/ 2297841. 
Esteve-Pérez, S., \& Mañez-Castillejo, J.A. (2008). The resource-based theory of the firm and firm survival. Small Business Economics, 30(3), 231-249. https://doi.org/10. 1007/s11187-006-9011-4.

Esteve-Pérez, S., Sanchis-Llopis, A., Sanchis-Llopis, J.A. (2010). A competing risks analysis of firms' exit. Empirical Economics, 38(2), 281-304. https://doi.org/10.1007/ s00181-009-0266-x.

Esteve-Pérez, S., Requena-Silvente, F., Pallardó-Lopez, V.J. (2013). The duration of firm-destination export relationships: Evidence from Spain, 1997-2006. Economic Inquiry, 51(1), 159-180. https://doi.org/10.1111/j.1465-7295.2012. 00460.x.

Fackler, D., Schnabel, C., Wagner, J. (2013). Establishment exits in Germany: the role of size and age. Small Business Economics, 41(3), 683-700. https://doi.org/10.1007/ s11187-012-9450-z.

Ferragina, A., Pittiglio, R., Reganati, F. (2012). Multinational status and firm exit in the Italian manufacturing and service sectors. Structural Change and Economic Dynamics, 23(4), 363-372. https://doi.org/10.1016/j.strueco.2011.10.002.

Fichman, M., \& Levinthal, D.A. (1991). Honeymoons and the liability of adolescence: A new perspective on duration dependence in social and organizational relationships. The Academy of Management Review, 16(2), 442-468. https://doi.org/10.5465/amr.1991.4278962.

Fligner, M.A., \& Policello, G.E. (1981). Robust rank procedures for the behrens-fisher problem. Journal of the American Statistical Association, 76(373), 162-168. https://doi.org/10.1080/01621459.1981.10477623.

Flikkema, M., De Man, A.-P., Castaldi, C. (2014). Are trademark counts a valid indicator of innovation? Results of an In-Depth Study of New Benelux Trademarks Filed by SMEs. Industry and Innovation, 21(4), 310-331. https://doi.org/10.1080/13662716.2014.934547.

Flikkema, M., Castaldi, C., de Man, A.-P., Seip, M. (2019). Trademarks' relatedness to product and service innovation: A branding strategy approach. Research Policy, 48(6), 1340-1353. https://doi.org/10.1016/j.respol.2019.01.018.

Fontana, R., \& Nesta, L. (2009). Product innovation and survival in a high-tech industry. Review of Industrial Organization, 34(4), 287-306. https://doi.org/10.1007/s11151-0099210-7.

Foster, L., Grim, C., Haltiwanger, J. (2016). Reallocation in the great recession: Cleansing or not? Journal of Labor Economics, 34(S1), S293-S331. https://doi.org/10.1086/ 682397.

Gallini, N.T. (2002). The economics of patents: Lessons from recent u.s. patent reform. Journal of Economic Perspectives, 16(2), 131-154. https://doi.org/10.1257/0895330027292.

Ginarte, J.C., \& Park, W.G. (1997). Determinants of patent rights: A cross-national study. Research Policy, 26(3), 283301. https://doi.org/10.1016/S0048-7333(97)00022-X.

Giovannetti, G., Ricchiuti, G., Velucchi, M. (2011). Size, innovation and internationalization: a survival analysis of Italian firms. Applied Economics, 43(12), 1511-1520. https://doi.org/10.1080/00036840802600566.

Godart, O., Görg, H., Hanley, A. (2012). Surviving the crisis: foreign multinationals versus domestic firms. The World Economy, 35, 1305-1321. https://doi.org/10.1111/j.14679701.2012.01485.x.
Grazzi, M., Piccardo, C., Vergari, C. (2018). Building a firm level dataset for the analysis of industrial dynamics and demography. Journal of Economic and Social Measurement, 43(3-4), 169-197. https://doi.org/10.3233/JEM180456.

Grazzi, M., Piccardo, C., Vergari, C. (2020). Concordance and complementarity in IP instruments. Industry \& Innovation, 27(7), 756-788. https://doi.org/10.1080/13662716.2020. 1726728.

Griliches, Z. (1981). Market value, R\&D, and patents. Economics Letters, 7(2), 183-187. https://doi.org/10.1016/ 0165-1765(87)90114-5.

Hall, B.H. (2000). Innovation and market value. In Barrell, R., Mason, G., O’Mahony, M. (Eds.) Productivity, innovation and economic performance (pp. 13-33). Cambridge: Cambridge University Press.

Hannan, M.T. (1998). Rethinking age dependence in organizational mortality: Logical formalizations. American Journal of Sociology, 104(1), 126-164. https://doi.org/10.1086/ 210004.

Headd, B. (2003). Redefining business success: Distinguishing between closure and failure. Small Business Economics, 21(1), 51-61. https://doi.org/10.1023/A:1024433630958.

Helmers, C., \& Rogers, M. (2010). Innovation and the survival of new firms in the UK. Review of Industrial Organization, 36(3), 227-248. https://doi.org/10.1007/s11151-0109247-7.

Heyman, F. (2007). Firm size or firm age? the effect on wages using matched employer-employee data. Labour, 21(2), 237-263. https://doi.org/10.1111/j.1467-9914.2007. 00377.x.

Infocamere (2019). Movimprese. Technical report, Infocamere, 2019. Available at: https://www.infocamere.it/movimprese.

Jenkins, S. (2004). Survival analysis. Unpublished manuscript. Institute for Social and Economic Research, University of Essex, Colchester, UK. URL https://www.iser.essex.ac.uk/ files/teaching/stephenj/ec968/pdfs/ec968st7.pdf.

Jensen, P.H., Webster, E., Buddelmeyer, H. (2008). Innovation, technological conditions and new firm survival. Economic Record, 84(267), 434-448. https://doi.org/10.1111/j.14754932.2008.00509.x.

Jovanovic, B. (1982). Selection and the evolution of industry. Econometrica, 50(3), 649-670. https://doi.org/10.2307/ 1912606.

Kaplan, E.L., \& Meier, P. (1958). Nonparametric estimation from incomplete observations. Journal of the American Statistical Association, 53(282), 457-481. https://doi.org/10.1080/01621459.1958.10501452.

Landini, F., Arrighetti, A., Lasagni, A. (2020). Economic crisis and firm exit: Do intangibles matter? Industry and Innovation, 27(5), 445-479. https://doi.org/10.1080/13662716. 2018.1544065 .

Masatoshi, K., Koichiro, O., Yuji, H. (2019). Does patenting help new-firm survival? Understanding heterogeneity among exit routes. Technical report.

Melitz, M.J. (2003). The impact of trade on intra-industry reallocations and aggregate industry productivity. Econometrica, 71(6), 1695-1725. https://doi.org/10.1111/1468-0262. 00467.

Mendonça, S., Pereira, T.S., Godinho, M.M. (2004). Trademarks as an indicator of innovation and industrial change. 
Research Policy, 33(9), 1385-1404. https://doi.org/10. 1016/j.respol.2004.09.005.

Mueller, S., \& Stegmaier, J. (2015). Economic failure and the role of plant age and size. Small Business Economics, 44(3), 621-638. https://doi.org/10.1007/s11187-014-9616-y.

Ortega-Argiles, R., \& Moreno, R. (2007). Firm competitive strategies and the likelihood of survival. the spanish case. Papers on entrepreneurship, growth and public policy 0507 Max Planck Institute of Economics.

Pérez, S.E., Llopis, A.S., Llopis, J.A.S. (2004). The determinants of survival of Spanish manufacturing firms. Review of Industrial Organization, 25(3), 251-273. https://doi.org/10.1007/s11151-004-1972-3.

Perry, M.K., \& Porter, R.H. (1985). Oligopoly and the incentive for horizontal merger. The American Economic Review, 75(1), 219-227.

Schary, M.A. (1991). The probability of exit. The RAND Journal of Economics, 22(3), 339-353. https://doi.org/10.2307/ 2601051.

Schautschick, P., \& Greenhalgh, C. (2016). Empirical studies of trade marks-the existing economic literature. Economics of Innovation and New Technology, 25(4), 358-390. https://doi.org/10.1080/10438599.2015.1064598.

Stinchcombe, A.L. (1965). Social structure and organizations. In March, J.P. (Ed.) Handbook of organizations (pp. 142193). Chicago: Rand McNally.
Strotmann, H. (2007). Entrepreneurial survival. Small Business Economics, 28(1), 87-104. https://doi.org/10.1007/ s11187-005-8859-z.

Toivanen, O., Stoneman, P., Bosworth, D. (2002). Innovation and the market value of UK firms, 1989-1995. Oxford Bulletin of Economics and Statistics, 64, 39-61. https://doi.org/10.1111/1468-0084.00002.

Tsoukas, S. (2011). Firm survival and financial development: Evidence from a panel of emerging asian economies. Journal of Banking \& Finance, 35(7), 1736-1752. https://doi.org/10.1016/j.jbankfin.2010.12.008.

Wagner, J. (2013). Exports, imports and firm survival: first evidence for manufacturing enterprises in Germany. Review of World Economics, 149(1), 113-130. https://doi.org/10.1007/s10290-012-0141-2.

Wagner, S., \& Cockburn, I. (2010). Patents and the survival of internet-related IPOs. Research Policy, 39(2), 214-228. https://doi.org/10.1016/j.respol.2009.12.003.

Zhang, T. (2003). A Monte Carlo study on non-parametric estimation of duration models with unobserved heterogeneity. Working Papers Memorandum 25/2003, Department of Economics University of Oslo.

Publisher's note Springer Nature remains neutral with regard to jurisdictional claims in published maps and institutional affiliations. 